\title{
Ethnobotanical knowledge of the lay people of Blouberg area (Pedi tribe), Limpopo Province, South Africa
}

\author{
Nkoana Ishmael Mongalo ${ }^{1 *}$ and Tshepiso Jan Makhafola ${ }^{2}$
}

\begin{abstract}
Background: Limpopo province, South Africa, has a rich plant diversity and is referred to as one of the hotspots areas within the country. The aim of the current work was to identify and document medicinal plant species used by the indigenous Pedi people of Blouberg area, Limpopo Province, South Africa.

Methods: A total of 40 informants which includes both traditional healers and medicinal plant sellers were randomly selected and asked about the plant species used in treatment of variety of infections using a structured questionnaire. Follow-up visits and various field walks were also used to identify and document various plant species used in Traditional medicine (TM). The interviews were carried out from April 2008 to June 2016 using indigenous language (Sehananwa).

Results: A total of 82 medicinal plants species belonging to 42 families have been collected, identified and documented. About $46.34 \%$ of the plant species were herbs, followed by trees (25.61\%), shrubs (20.73\%) and climbers (7.32\%). The most used plant parts are roots and rhizomes (58.58\%). Peltophorum africanum Sond revealed frequency index of greater than 70 and is used in combination with other plants species to treat various pathogenic infections. Most of the plant species reported are used in the treatment of sexually transmitted infections (24), management of HIV-AIDS (15) and stomach ache (14). Our informants indicated that the use of plant medicines in combinations is also applied to cure pathogenic infections.

Conclusion: The current study demonstrate that the indigenous people of Blouberg area, Limpopo Province harbours an important information about the vegetation around them. The plant species are used in the treatment of various pathogenic infections, offers fruits as additional source of food and form integral part of other medicinal products that may in turn produce income.
\end{abstract}

Keywords: Blouberg area, Limpopo Province, Ethno-medicine, Ethnobotanical urvey, Medicinal plants, South Africa

\section{Background}

Limpopo Province is mostly dominated by the Pedi (57\%), Tsonga (23\%) and Venda (12\%), ethnic groups while English and Afrikaans speaker only constitutes less than $4 \%$ combined [1]. However, there are other unofficial languages which includes Khelobedu, Setlokwa and Sehananwa falling under the Sotho or Pedi speaking people. Blouberg area, dominated by Pedi tribe, comprise of only two main health care facilities (Blouberg and Helena-Franz Hospital), a small remote town known

\footnotetext{
* Correspondence: ishmaelmongalo@gmail.com

${ }^{1}$ College of Agriculture and Environmental Science (CAES) Laboratories,

University of South Africa, Private BagX06, Johannesburg 0710, South Africa

Full list of author information is available at the end of the article
}

as Senwabarwana and a few game reserves (Blouberg and Maleboho nature reserves). The population in this area, like in other rural African communities is reliant on traditional medicine (TM) as their basic source of health care [2,3]. The other possible challenges in health care facilities within the study site may include long distances travelled to hospitals, long waiting on the queues, drug shortages, lack of proper laboratories with state of the art scientific equipment and attitudes of the health workers [4]. The area is one of the medicinal plants hotspots with only little plant species documented in the few surveys taken recently within the Province [5-9], but not strictly focussing on Blouberg area.

(c) The Author(s). 2018 Open Access This article is distributed under the terms of the Creative Commons Attribution 4.0 International License (http://creativecommons.org/licenses/by/4.0/), which permits unrestricted use, distribution, and reproduction in any medium, provided you give appropriate credit to the original author(s) and the source, provide a link to the Creative Commons license, and indicate if changes were made. The Creative Commons Public Domain Dedication waiver (http://creativecommons.org/publicdomain/zero/1.0/) applies to the data made available in this article, unless otherwise stated. 
Several ethnobotanical studies have been taken world-wide, documenting different plant species and preserving the indigenous knowledge of various communities [10-15]. Most of these surveys may well serve as possible leads for the discovery of potent new drugs that may be used to combat most harmful infections that pose a serious threat to human and animal health. Traditional people believe in using TM or herbal therapy in treating various infections, mostly because plant species are abundant in nature in their surrounding environment, less priced and are believed to pose less or no side effects. Moreover, it is believed that herbal therapy is holistic, integrating the emotional, spiritual and mental well-being of the patients [16]. Furthermore, TM is culturally acceptable and there is a belief that it purges out any infection after treatment from hospitals [17]. Besides being the main source of drugs in the current threatened health care system with emerging multiple resistant organisms, the traditional medicine still receives little attention world-wide [18].

The enormous rise in HIV-AIDS infections in Africa pose a further threat to human life, resulting in variety of opportunistic infections which may include various skin infections inflammatory disorders, various forms of candidiasis, reactivation of the TB germ and other possible pulmonary infections, multiple forms of lymphoma and various Herpes infections [19-21]. The aim of the current work is to identify and document various plant species used by the lay people of Blouberg (Hananwa).

\section{Methods}

\section{Study area}

South Africa (Fig. 1) is divided into nine Provinces. Blouberg area, indigenously known as Hananwa, is situated in the Limpopo Province, $30 \mathrm{~km}$ north of Dendron and $95 \mathrm{~km}$ from Polokwane, and connects South Africa to both Botswana and Zimbabwe. Geographically, it is a deep rural area, mountainous and located between the Waterberg Wetlands and the Dongola Trans-frontier and extends right up to the Botswana border [22].

The area is under kingship of the Leboho family and occupies an area of approximately $5054 \mathrm{~km}^{2}$ and a total population of about 166,243 people [23]. Big rivers such as Bohlokwe, Tswatšane, Mmatšope and other small rivers provide water to various livestock in the area. Mogalakwena River, with its rich biota which includes crocodiles, also cuts into the area. Various sites on the mountain Blouberg- a green mountain throughout the year, serves different purposes. Ploughing fields, burial site for the kings of the past and hunting grounds are amongst the most important sites in the mountain.

\section{Selection of informants and interviews}

A total of 40 informants which includes 20 traditional healers and 20 medicinal plants sellers from Blouberg area have been randomly sampled from a pool of informants attending meeting relating to African Dingaka Association of South Africa at Blouberg area from April 2008 to June 2016 using structured questionnaires, follow-up visits and field trips. Various visits were made to establish a rapport and more often assisting in plant collection for use in the African surgeries (consulting rooms). Informants were mostly from villages such as Lethaleng, Ga-Mochemi, Ditatšu, Ga-Rammutla A, Pickum B, Ga-Mashalane, Ga-Mmamolele, Ga-Broekmane, Dilaeneng, Ga-Machaba, Ga-Kibi, Ga-Mmaleboho, Ga-Radimang, Ga-Manaka, Sewale, Bosehla, Mohlabeng-wa-Malokela, Gwarung, Ga-Kobe, Sebotlane, Ga-Kibi, Devrede, Makgabeng, Marobjane, Inveraan and Bull-bull. The informants agreed to furnish information regarding the indigenous medicinal plant species used in the treatment of various infections treated by both healers and plant sellers using questionnaires, while noting the plant species named using Sehananwa as a local language. At a later date, informants were requested to identify the plant species at various collection sites.

Follow-up visits were later conducted with the intention of verifying the information given by informants, particularly the correspondence of indigenous names, and then later request further information on whether the plant species mentioned are used as a single plant material or in combination with other plant species. Only plant species mentioned by the informants at least three times were eligible for documentation [24]. Data on combinations of plants in the treatment of infections was documented, including mode of preparation and route of administration.

\section{Collection and identification of medicinal plants}

The plant species were collected, pressed and identified by botanists in the Department of Life and Consumer Sciences, Horticulture and College of Agriculture and Environmental Science (CAES) laboratories. The unknown plant materials to the authors and staff in the College of Agriculture and Environmental Sciences were send to National Botanical Institute (NBI) in Pretoria for identification (The personnel who assisted in identification includes Klopper, R.R., Mothogoane, M.S., Makgakga, M.C., Makwarela, L.E., Archer, R.H., Nkonki, T., Ready, J.A., Bester, S.P., Meyer, J.J., Ruiters, A.K. and Welamn, N). The voucher specimen of all the collected plant species were then lodged at University of South Africa herbarium in Florida. Other plant materials were also deposited into the NBI herbarium. These includes Cissus cornifolia, Neorautanenia mitis, Pollichia campestris, Ipomoea albivenia, Pterodiscus kellerianus, Ehretia rigida and Aptosimum lineare.

\section{Data analysis}

The analysis of data was carried out using both descriptive and inferential statistics using percentages and frequencies. The frequency index (FI), informant consensus 


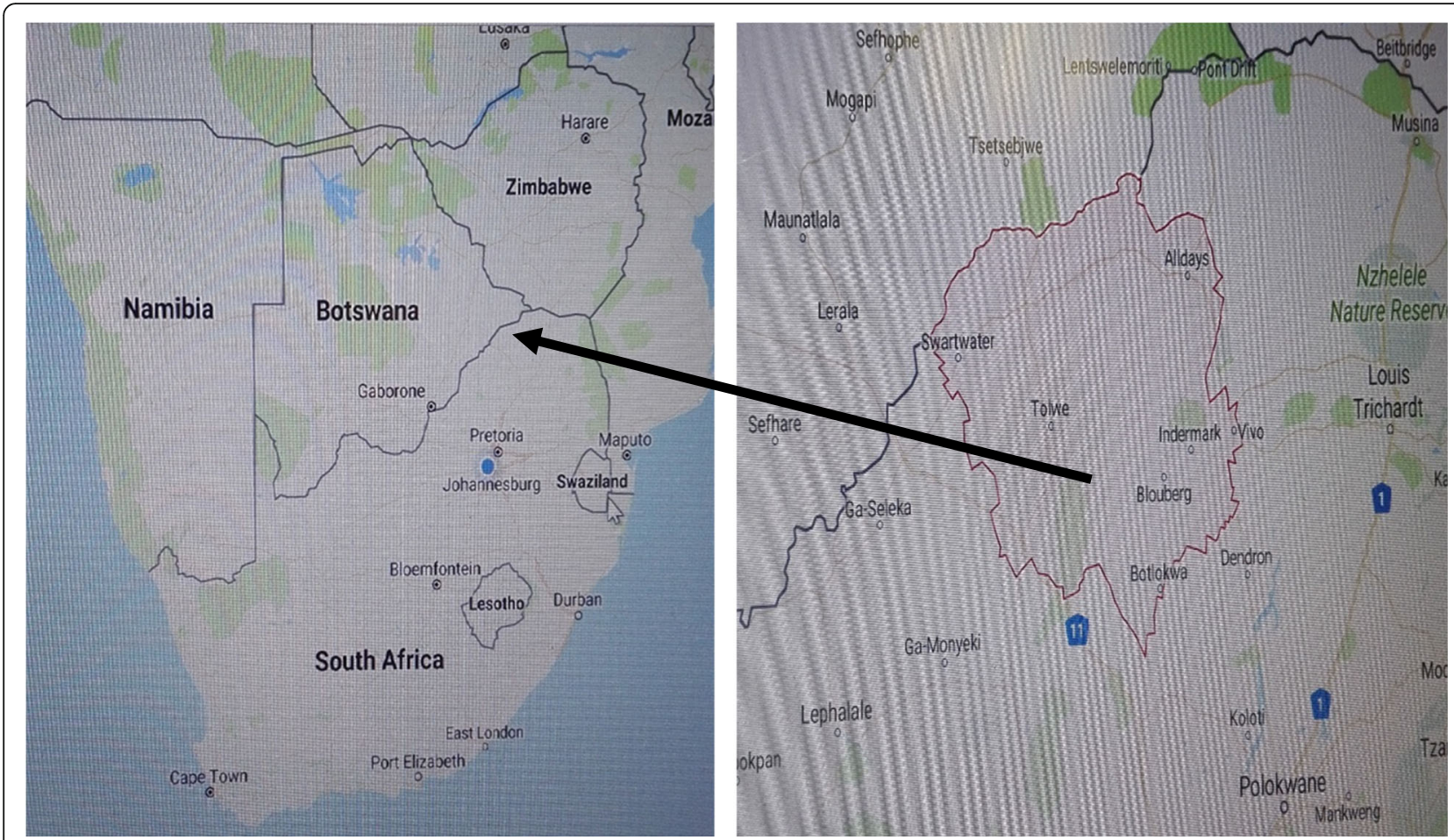

Fig. 1 Map of South Africa, locating Blouberg area (red coloured area)

factor $\left(\mathrm{F}_{\mathrm{ic}}\right)$ and Fidelity levels $(\mathrm{FL})$ were calculated and compared. FI of the documented plant species were calculated using the formula:

$$
\mathrm{FI}=\mathrm{FC} / N \times 100,
$$

Where FI is the frequency of citation for one plant species by informants, FC is the number of informants who cited the use of the plant species and $N$ is the total number of informants $[25,26] . F_{\text {ic }}$ was calculated to determine the homogeneity of the information provided by the informants using the formula:

$$
\mathrm{FIC}=\mathrm{N}_{\mathrm{ur}}-\mathrm{N}_{\mathrm{taxa}} / \mathrm{N}_{\mathrm{ur}}-1
$$

Where $\mathrm{N}_{\mathrm{ur}}$ is the number of use reports, $\mathrm{N}_{\text {taxa }}$ is the number of species in each use category [27], while FL was calculated using the formula:

$$
\mathrm{FL}=\mathrm{I}_{\mathrm{p}} / \mathrm{I}_{\mathrm{u}} \mathrm{X} 100
$$

Where $I_{p}$ is the number of informants who suggested the use of the species for the same major ailment and $\mathrm{I}_{\mathrm{u}}$ represents the total number of informants who mentioned the species for any use [28].

\section{Results}

\section{Socio-demographic information and diversity of plants} species

The communities around Blouberg area use diverse flora in treatment of various ailments and local people possess a rich traditional knowledge on the use of medicinal plants as medicine. The age of our informants ranged from 30 to 88 years (Table 1). About $64 \%$ of our informants are aged between 40 and 65 years of age while $10 \%$ of our informants are below the age of 40 years. About $40 \%$ of our informants have never been to school and only one of the 40 participants possess a diploma in Education and is also a well-known traditional healer. A total of 82 plant species belonging to 42 different families were recorded in the current study (Table 2). Families such as Fabaceae (14.63\%), Malvaceae (8.54\%), Apocynaceae (7.32\%), Solanaceae (6.10\%), Convolvulaceae (4.88\%), Euphorbiaceae $(3.66 \%)$ and Vitaceae $(3.66 \%)$ were well represented (Table 3) and are dominant, while families such as Rubiaceae, Olacaceae, Loganiaceae, Ebenaceae, Celastraceae, Asphodelaceae and Anacardiaceae reported 2.44\% each. The other families recorded one plant species each.

\section{Growth forms, plant parts used and mode of administration of plant species}

The reported plant species were dominated by herbs (46.34\%), followed by trees (25.61\%), shrubs (20.73) and climbers (7.32\%) (Fig. 2). Out of the reported plant 
Table 1 Demographic of informants

\begin{tabular}{|c|c|c|c|c|c|c|c|c|c|c|c|}
\hline \multirow[t]{2}{*}{ Informants category } & \multirow[t]{2}{*}{ Males } & \multirow[t]{2}{*}{ Females } & \multicolumn{4}{|c|}{ Age groups } & \multicolumn{5}{|c|}{ Level of Education } \\
\hline & & & $30-40$ & $41-50$ & $51-65$ & Above 65 & $\begin{array}{l}\text { Never been } \\
\text { to school }\end{array}$ & $\begin{array}{l}\text { ABET } \\
\text { Education }\end{array}$ & $\begin{array}{l}\text { Primary } \\
\text { Education }\end{array}$ & $\begin{array}{l}\text { Secondary } \\
\text { Education }\end{array}$ & $\begin{array}{l}\text { Tertiary } \\
\text { Education }\end{array}$ \\
\hline Traditional healers & 8 & 12 & - & 1 & 9 & 10 & 6 & 4 & 3 & 6 & 1 \\
\hline Plant sellers & 14 & 6 & 4 & 12 & 4 & - & 10 & 0 & 2 & 8 & 0 \\
\hline Percentage & 55 & 45 & 10 & 32.5 & 32.5 & 25 & 40 & 10 & 12.5 & 35 & 2.5 \\
\hline
\end{tabular}

species, roots and bulbs (underground plant material) were the most used (58.6\%), followed by stem bark (13.1\%), whole plant (12.1\%) and leaves (11.1\%) (Fig. 3).

Most of the plants materials are boiled and taken orally (73\%) when treating various types of infections (Fig. 4). The other plant species may be topically applied (10.89\%) to the skin, while the others may be burned $(5.94 \%)$ or used to wash and rinse (5.94\%) the infected body part. The inhalation, nasal administration, and plant materials which may be blown reported less than $5 \%$ each.

\section{Ailments treated and consensus agreement}

The most reported plant species are used in the treatment of sexually transmitted infections (24) followed by those used in the management of HIV-AIDS related infections (15), stomach ache (14) and plant species used in the treatment of ethno-veterinary infections (9) while the informant consensus factors $\left(\mathrm{F}_{\mathrm{ic}}\right)$ of the mentioned ailment categories ranged from 0.78 to 1 as shown in Table 4. About 25 species revealed FL value of $100 \%$ against variety of diseases (Table 5).

\section{Combination studies and plant species with Frerequency index $\geq 70$}

Eight medicinal plants species such as Elephantorrhiza elephantine, Waltheria indica, Securidaca longipedunculata, Blepharis diversispina, Peltophorum africanum, Cissus quadrangularis, Sclerocarrya birrea and Elephantorrhiza burkei reported FI value $\geq 70$ hence have some pharmacological activities reported from literature (Table 6). About 12 combinations of medicinal plants species have been recorded in the current study (Table 7). Waltheria indica appeared in six of the 12 combinations, accounting to $50 \%$ and is used in the treatment of stomach ache, sexually transmitted infections, infertility, diarrhoea and strengthening of immunity in new born babies.

\section{Discussions}

\section{Demographic information and diversity of use of plant species}

Traditional knowledge is mainly transferred from one generation to the next through mouth and such information may evacuate and disappear for good with time or becomes limited as life evolves [29, 30]. The demographic information of selected informant's data shows that males (55\%) dominates in the traditional knowledge compared to $45 \%$ of females. Contrarily, other authors reported the females to dominate in the traditional knowledge [31, 32].

The families such as Fabaceae and Malvaceae are dominant in the current study, reporting 14.63 and $8.54 \%$ respectively. The dominance of the Fabaceae has also been reported several times in ethnobotanical surveys at different localities [33] world-wide. The use of the branches, sap and seeds were all reported to be much lesser. In the current study, the use of the underground plant part contributes (58.6\%), while stem bark reported 13.1\%. The use of underground, stem bark and whole plant (especially herbs which are uprooted) is of major concern as it is extremely detrimental to the health of the plant species and may lead to plant species extinction.

\section{The informant consensus agreement}

The technique is designed to highlight medicinal plant species that have a healing potential for a specific major illness. The plant species in major disease category, with

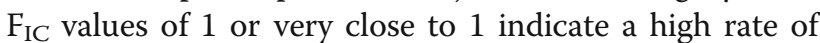
informant consensus on plant species used against the major specific illness [28]. In the current work, the plant species used in the treatment of joints, fractured bones, anti-poison, aphrodisiac, chest complaints, tonsillitis, asthma, vaal-sick and toothache reported $F_{I C}$ values of 1 . A similar trend has been observed elsewhere in other countries [34, 35]. However, it should be noted that the number of species in the above mentioned ailment categories is also equivalent to1.

\section{Fidelity levels $(\mathrm{FL})$ of the preferred medicinal plant species}

Fidelity level is designed to reveal the percentage of informants claiming the use of a certain plant for the same purpose [36]. FL values of documented plant species are reported in Table 5.

In the current study, about 25 species revealed FL value of $100 \%$ against variety of diseases, suggesting that the informant's state of knowledge is common when it comes to the uses of such plant species. Although Mimusops zeyheri and Raphionacme hirsuta revealed FL value of $100 \%$, there is no data in the literature supporting the pharmacological effect of such species against 


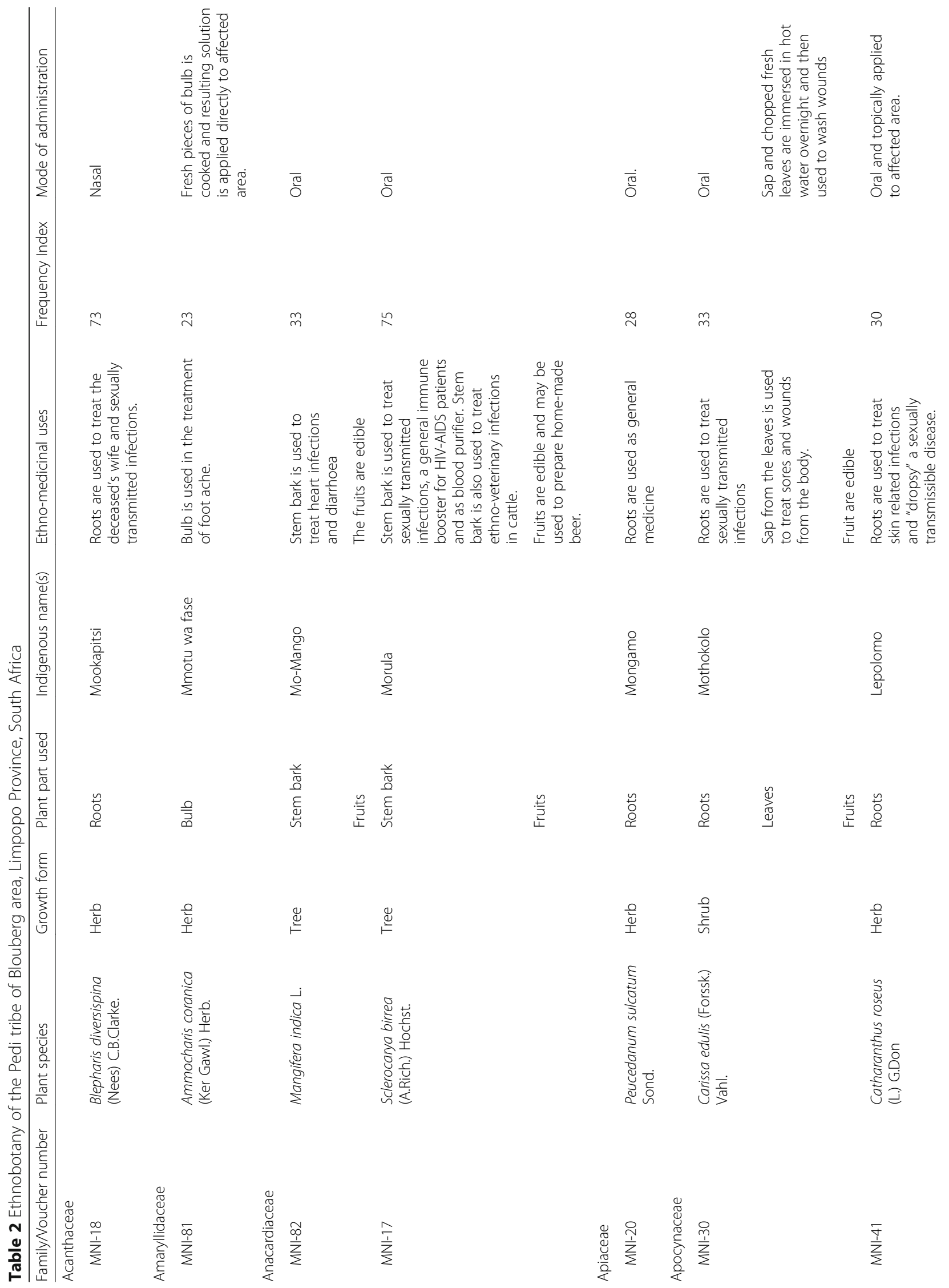


Mongalo and Makhafola Journal of Ethnobiology and Ethnomedicine (2018) 14:46

Page 6 of 23

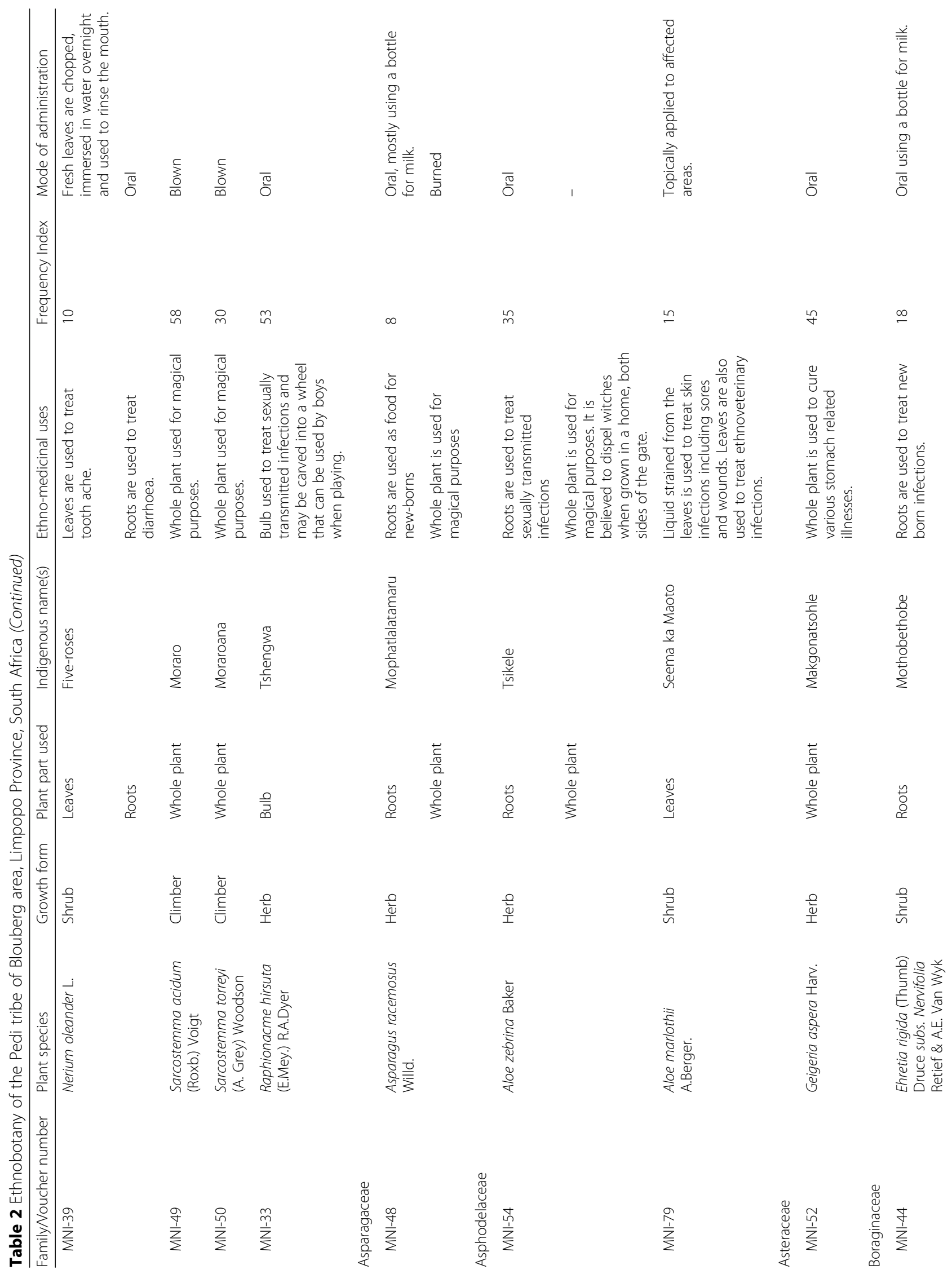


Mongalo and Makhafola Journal of Ethnobiology and Ethnomedicine (2018) 14:46

Page 7 of 23

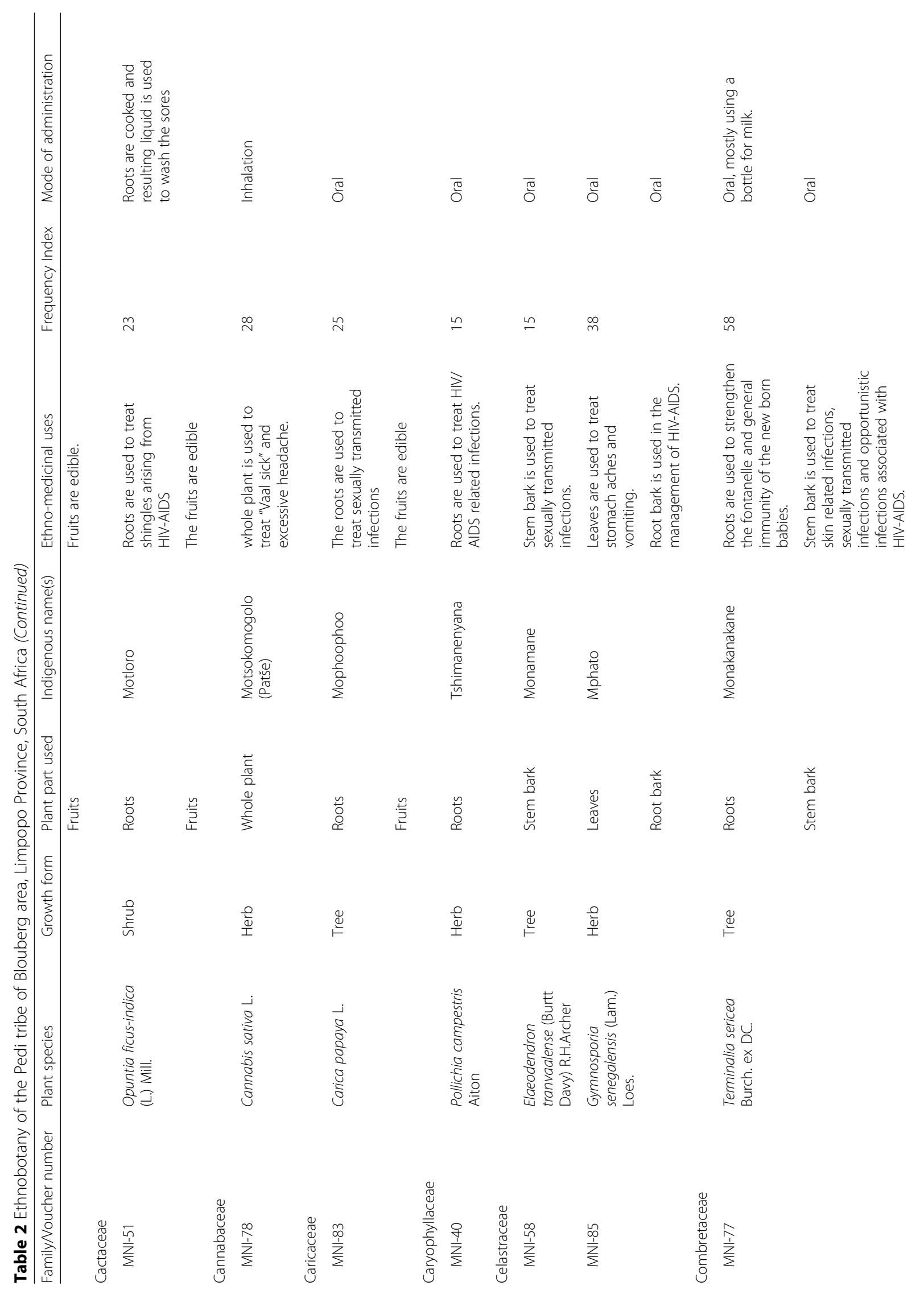




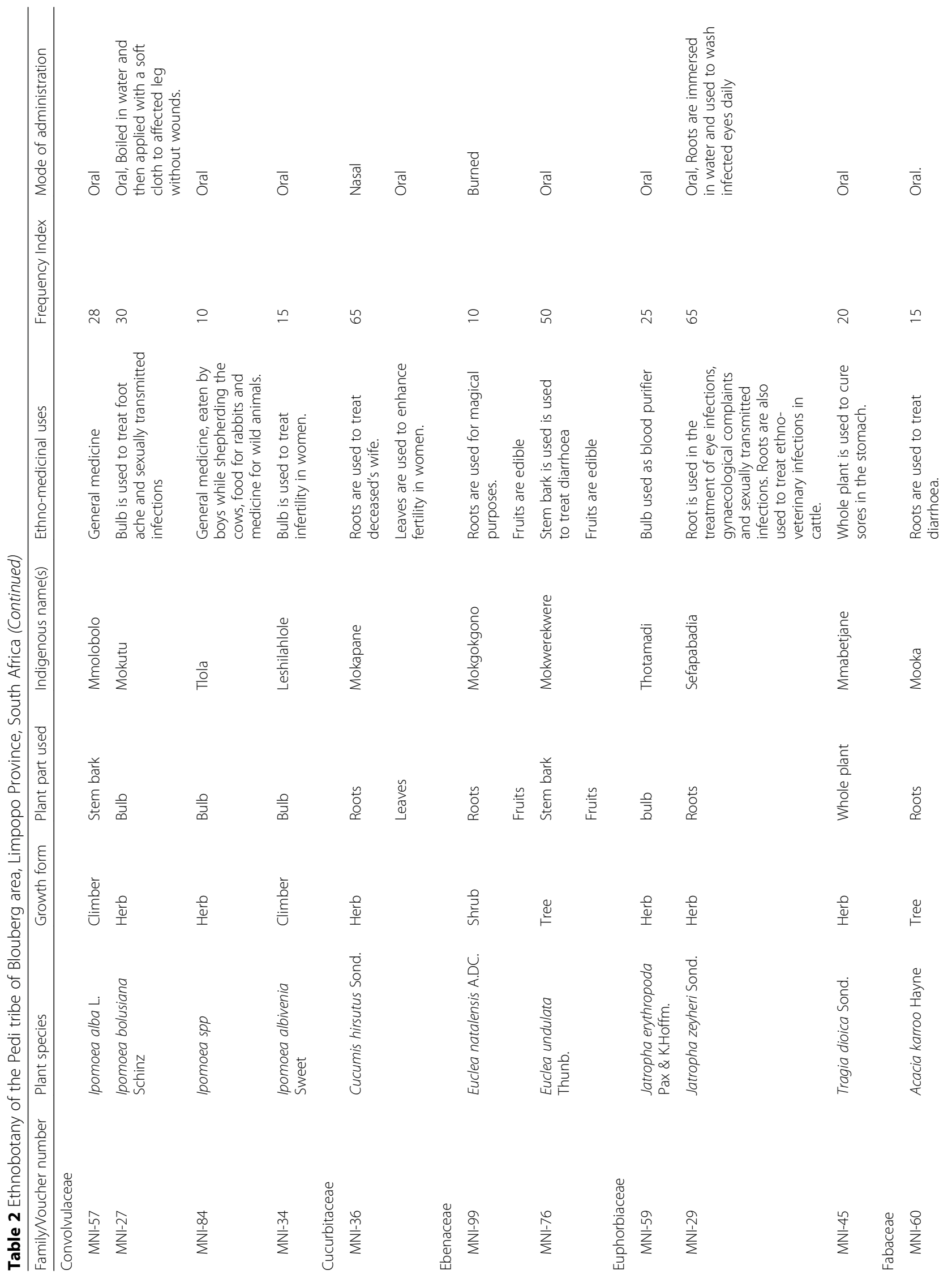




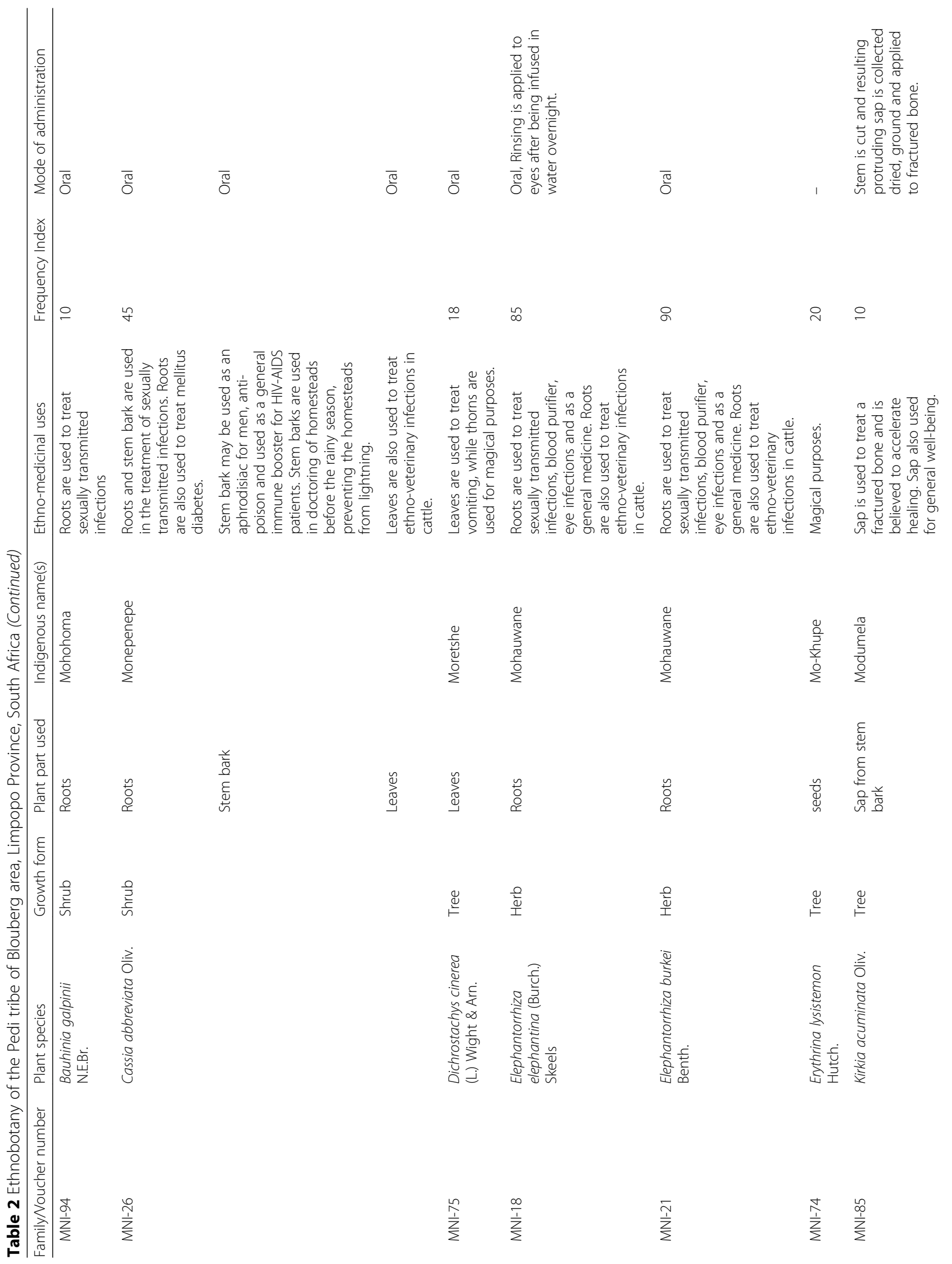




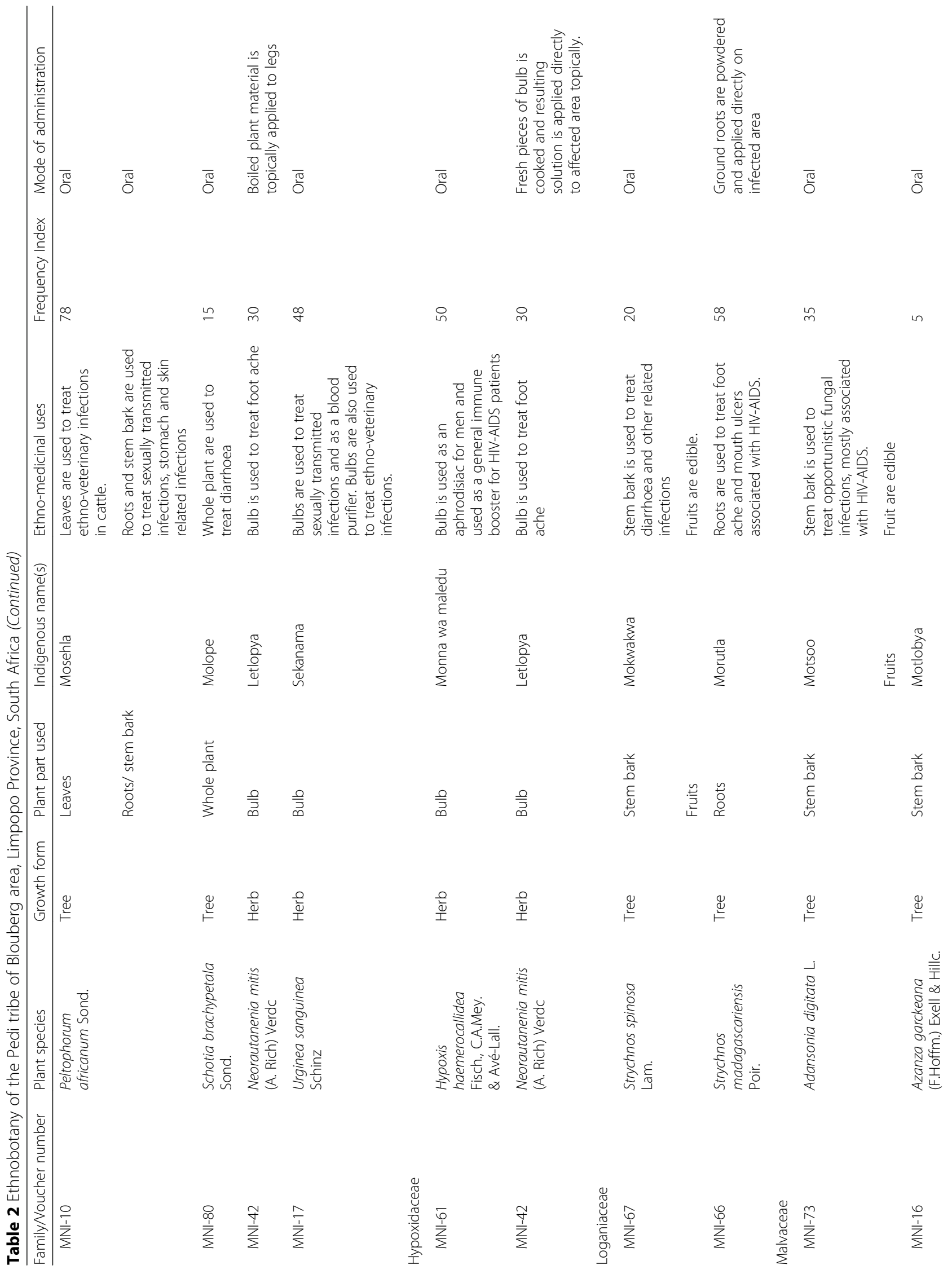




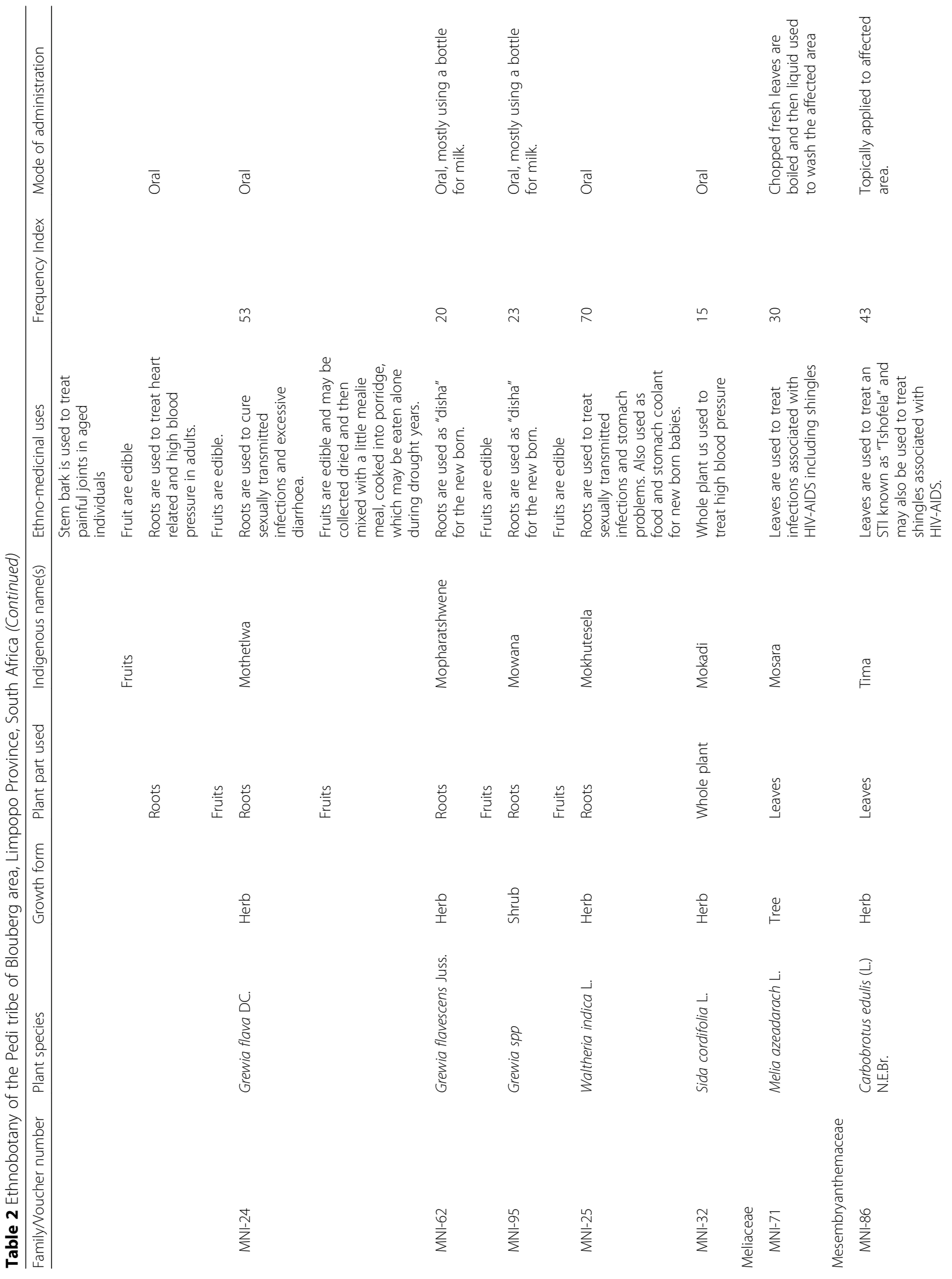




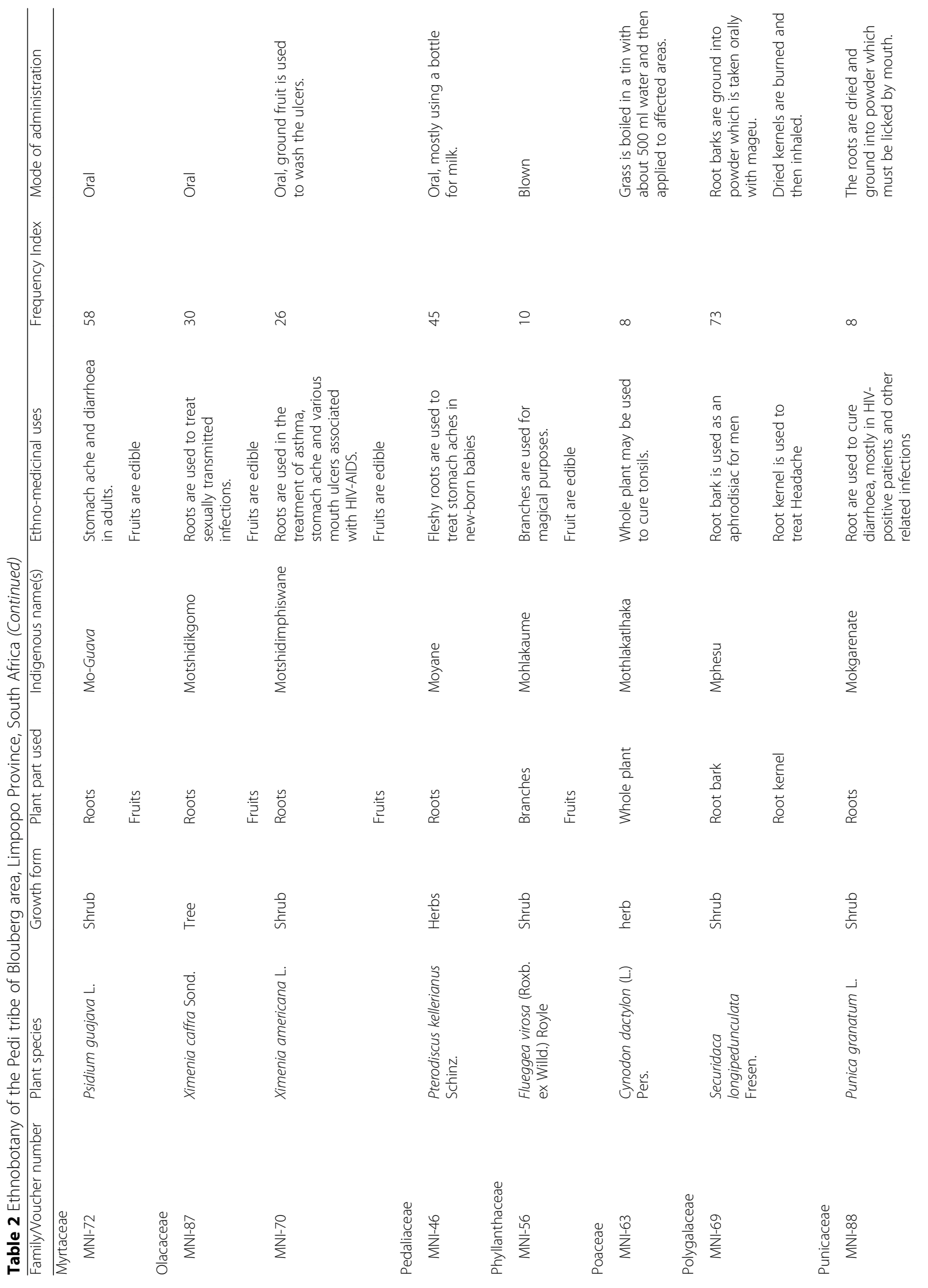




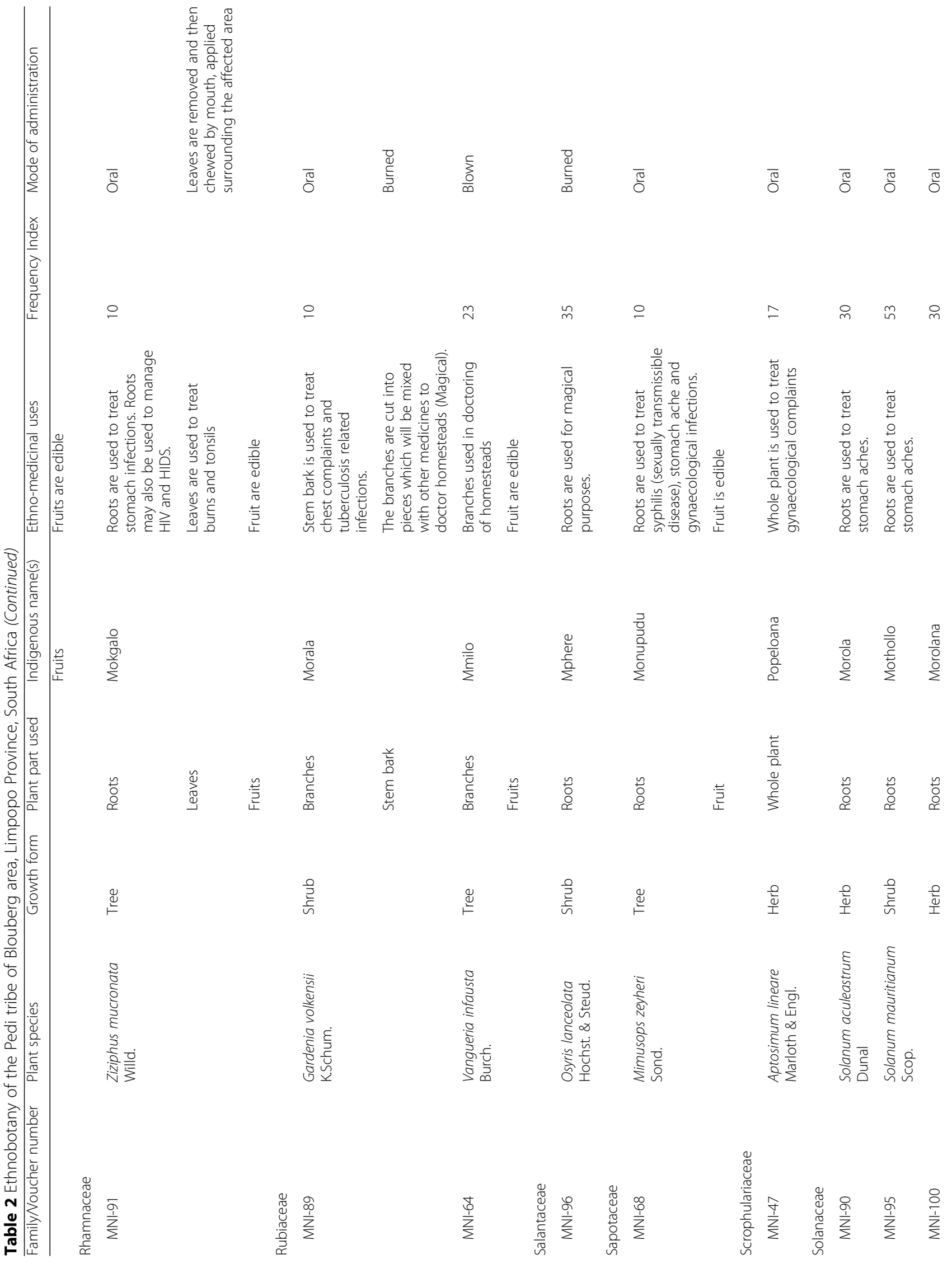




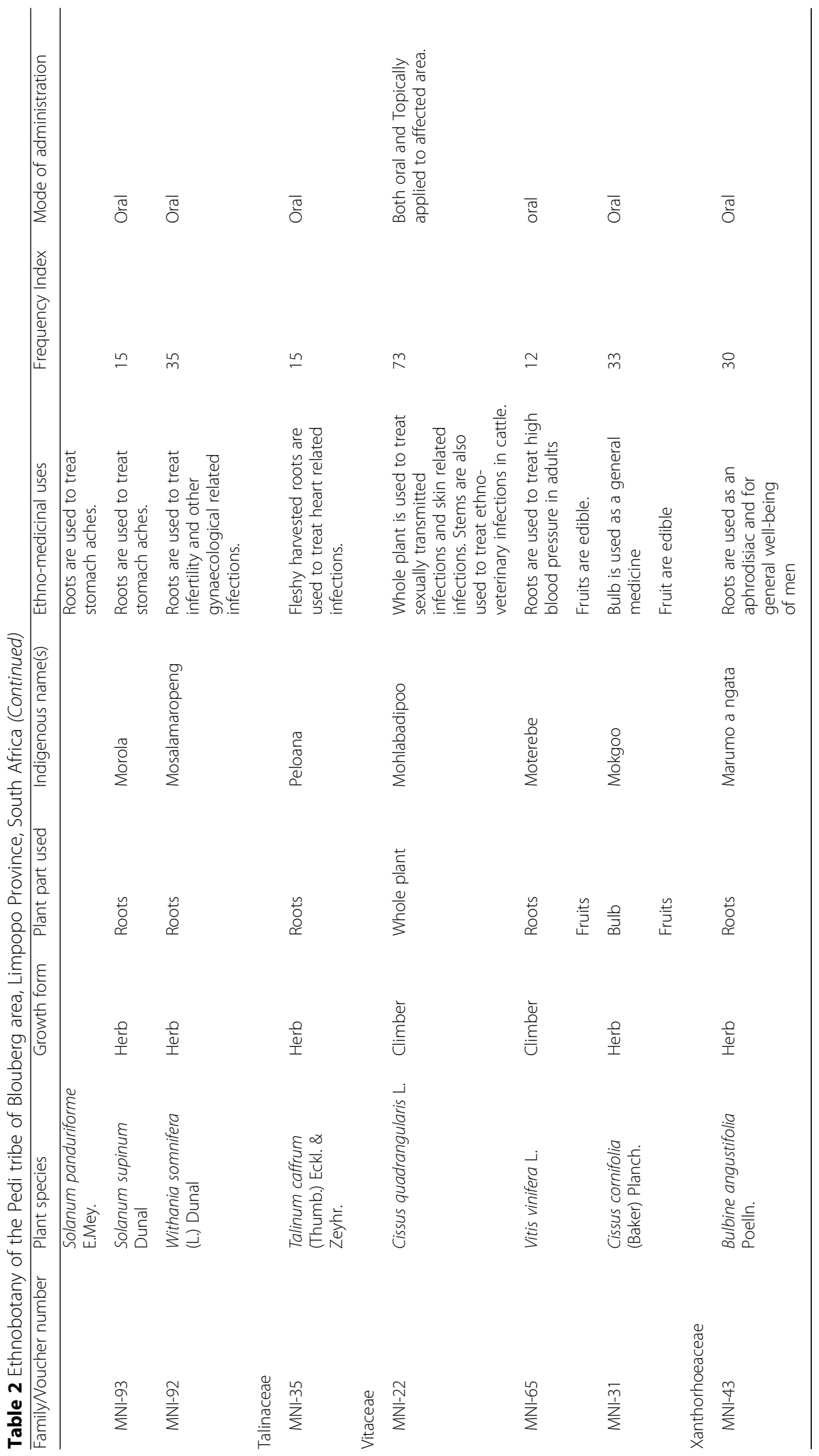


Table 3 Plant families with the largest (At least 3 species reported) number of species

\begin{tabular}{lll}
\hline Family name & Number of species & Percentage \\
\hline Fabaceae & 12 & 14.63 \\
Malvaceae & 7 & 8.54 \\
Apocynaceae & 6 & 7.32 \\
Solanaceae & 5 & 6.10 \\
Convolvulaceae & 4 & 4.88 \\
Euphorbiaceae & 3 & 3.66 \\
Vitaceae & 3 & 3.66 \\
Rubiaceae & 2 & 2.44 \\
Olacaceae & 2 & 2.44 \\
Loganiaceae & 2 & 2.44 \\
Ebenaceae & 2 & 2.44 \\
Celastraceae & 2 & 2.44 \\
Asphodelaceae & 2 & 2.44 \\
Anacardiaceae & 2 & 2.44 \\
\hline
\end{tabular}

pathogenic strains belonging to the traditional sphere of sexually transmitted infections.

It should also be noted that three plant species, such as Bauhinia galpinii, Elephantorrhiza burkei and Cassia abbreviata, from family Fabaceae appeared as some of the preferred plant species used against sexually transmitted infections, eye infections and as anti-poison respectively. Furthermore, Peltophorum africanum, Eephantorrhiza elephantine, Elephantorrhiza burkei and revealed frequency index (FI) values of 78, 85 and 90 respectively (Table 2). These data suggests that the family Fabaceae is generally important and used in the treatment of various human and animal infections. Although E. burkei in the current study is preferred to treat eye infections, it was also reported in the treatment of diarrhoea within other Bapedi

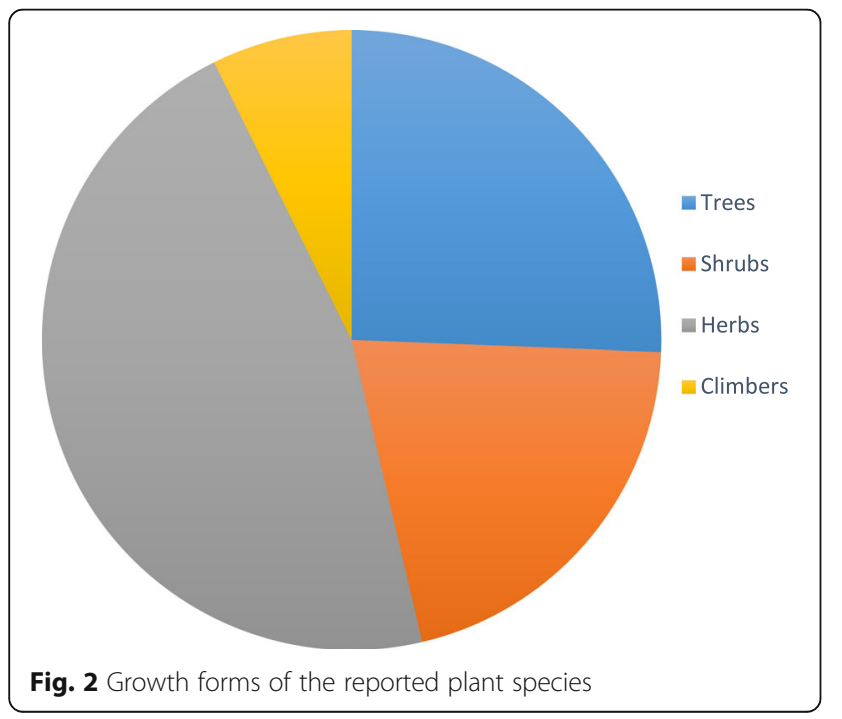

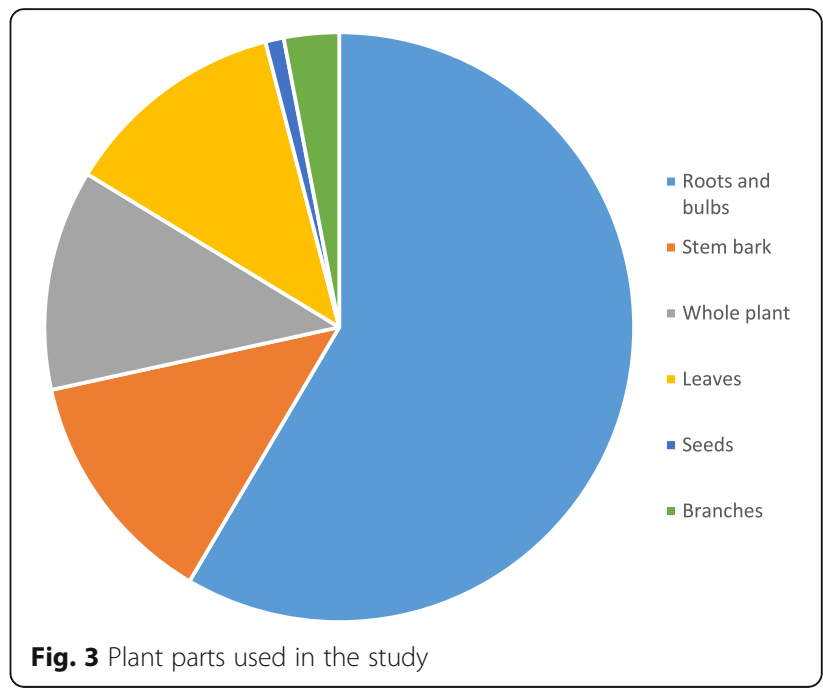

groups [37]. These difference may well suggest that the traditional knowledge on use of plant species in the treatment of infections may differ from one locality to the other. Although the current work revealed most preferred species used in the treatment of various pathogenic infections, the biological activity of such medicinal plants still needs to be explored and verified experimentally. Furthermore, the plant species with high FL values are of greater importance in treating the related human and animal infections from the study site.

\section{Plant uses and ailments treated}

The plant species reported in the current study are mostly used for treatment of human and animal infections while others are used for magical purposes. The most reported plant species are used in the treatment of sexually transmitted infections (24) followed by those used in the management of HIV-AIDS related infections (15), stomach ache (14) and plant species used in the

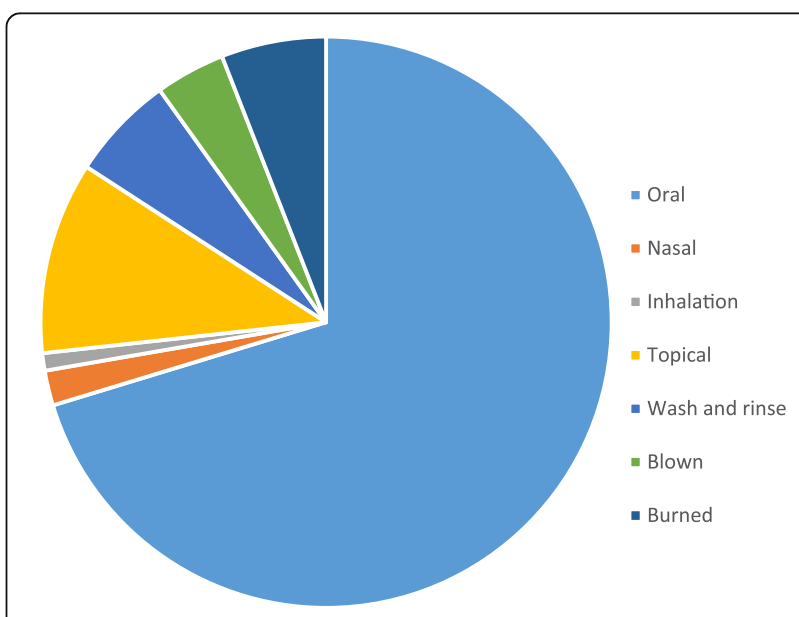

Fig. 4 Mode of administration of reported medicinal plants 
Table 4 Consensus agreement about uses of medicinal plants for important ailment categories

\begin{tabular}{|c|c|c|c|}
\hline Ailment category & $N_{\text {taxa }}$ & $\mathrm{N}_{\mathrm{ur}}$ & $F_{i c}$ \\
\hline High blood pressure & 3 & 10 & 0.78 \\
\hline Joints & 1 & 3 & 1 \\
\hline Fractured bones & 1 & 4 & 1 \\
\hline Anti-poison & 1 & 3 & 1 \\
\hline Aphrodisiac & 4 & 37 & 0.92 \\
\hline Diabetes & 1 & 3 & 1 \\
\hline Eye infections & 3 & 30 & 0.93 \\
\hline Asthma & 1 & 4 & 1 \\
\hline Tonsillitis & 2 & 6 & 1 \\
\hline Chest complaints & 1 & 3 & 1 \\
\hline Gynaecological complaints & 6 & 37 & 0.86 \\
\hline vomiting & 2 & 8 & 0.86 \\
\hline Headache & 2 & 13 & 0.92 \\
\hline Vaal sick & 1 & 7 & 1 \\
\hline Stomach ache & 14 & 114 & 0.88 \\
\hline New born infections & 7 & 47 & 0.88 \\
\hline Diarrhoea & 7 & 43 & 0.86 \\
\hline Tooth ache & 1 & 2 & 1 \\
\hline Skin infections & 5 & 28 & 0.85 \\
\hline Sores and wounds & 3 & 7 & 0.67 \\
\hline General medicine & 6 & 46 & 0.89 \\
\hline Ethno-veterinary infections & 9 & 44 & 0.81 \\
\hline Blood purifier & 5 & 35 & 0.88 \\
\hline Management of HIV-AIDS & 15 & 110 & 0.80 \\
\hline Heart infections & 3 & 16 & 0.87 \\
\hline Foot ache & 4 & 39 & 0.92 \\
\hline Deceased's wife & 2 & 49 & 0.98 \\
\hline Sexually transmitted infections & 24 & 209 & 0.89 \\
\hline \multicolumn{4}{|c|}{ Some taxa falls in more than one ailment categories } \\
\hline
\end{tabular}

treatment of ethno-veterinary infections (9). These results agrees with those of Peltzer et al., [38] who reported sexually transmitted infections to be mostly encountered and treated by African traditional healers. Amazingly, only a single plant each is reported to be used to treat pulmonary infections, mellitus diabetes and asthma.

Out of all the named medicinal plants in our survey, Gardenia volskensii is the only plant species reported to treat pulmonary related infections including tuberculosis. However, some of our informants revealed that for such purposes, bones from the chest of the Ostrich and nest of a dove "leeba" are chopped together and then administered to the patient. We found this difficult to validate scientifically as the doves may use different plant materials to build the nest and the age and gender of the ostrich was not identified in any of our informants.
Solanum species are used to treat stomach related illnesses. One of our informants revealed that a mixture of a variety of Solanum species is the perfect solution to various stomach disorders and further used a name "Merolanarolana" referring to variety of such species when hiding the prescription form the patients. It should be noted that from the multi-purpose plant species reported, $28 \%$ species bears fruits and are identified as food plants as well. According to our informants, the use of the species as foodstuffs is not very important as there are no markets for such fruits within the study sites. However, the fruits are used as addition to foods within families and also eaten by boys when shepherding the cows on the mountains. The treatment of infections is more important than the food value. For the purpose of food, the indigenous people are reliant upon the agricultural crops such as maize, wheat, potatoes and leafy vegetables which are grown mainly during the summer season.

\section{Magical and ethno-veterinary plants species}

Out of 82 plant species reported in the study, about 12 plants are used for magical purposes, while 9 species are used in the treatment of various ethno-veterinary infections. Sarcostema acidium and Cassia abbreviata are the most reported magical plant species with frequency index of 58 and 45 respectively (Table 2), while Elephantorrhiza burkei and Elephathorrhiza elephantina are preferred for ethnoveterinary use with frequency index of 90 and 85 respectively. Plant species reported within this category are believed to be used to doctor homesteads there by protecting them from lightning, dispel the witches, returning some illnesses and calling upon some ancestral spirits. Cassia abbreviata is used for many other uses in various communities. However, the Pedi tribe use the multi-stemmed species mostly in the doctoring of homesteads. The multi-stems (Fig. 5) are believed to symbolise the number of huts in the family that might comprise of extended family members and a number of wives belonging to one husband [39].

\section{Food plants}

Out of 82 plant species, 23 plants (28\%) bear fruits are identified as food plants. Strychnos madagascariensis and Psidium guajava reported the highest FI value of 58, each while Azanza garckeana reported the lowest FI value of 5 . Our current report corroborate that of Musina and Maroyi [40] who reported species such as Scleorcarrya birrea, Mangifera indica, Psidium guajava, Punica granatum and Vanguera infausta being used as food plants within Capricorn District, Limpopo Province. According to our knowledge, Cissus cornifolia was reported the first time within the country as a food source. However, it should be noted that the ethnobotanical survey of both the domesticated and wild edible fruits as sources of food 
Table 5 Fidelity levels (FL) of plant species used for various uses by key informants

\begin{tabular}{|c|c|c|c|c|}
\hline Medicinal Plant species & Therapeutic uses & $I_{p}$ & $I_{u}$ & $\mathrm{FL} \%$ \\
\hline Bauhinia galpinii & Sexually transmitted infections & 4 & 4 & 100 \\
\hline Mimusops zeyheri & Sexually transmitted infections & 4 & 4 & 100 \\
\hline Raphionacme hirsuta & Sexually transmitted infections & 16 & 21 & 72 \\
\hline Pollichia campestris & Management of HIV-AIDS & 6 & 6 & 100 \\
\hline Melia azeadarach & Management of HIV-AIDS & 12 & 12 & 100 \\
\hline Adansonia digitata & Management of HIV-AIDS & 9 & 12 & 75 \\
\hline Geigeria aspera & Stomach related infections & 18 & 18 & 100 \\
\hline Tragia dioica & Stomach related infections & 8 & 8 & 100 \\
\hline Solanum aculeastrum & Stomach related infections & 12 & 12 & 100 \\
\hline Solanum mauritianum & Stomach related infections & 21 & 21 & 100 \\
\hline Solanum supicum & Stomach related infections & 6 & 6 & 100 \\
\hline Securidaca longipedunculata & Aphrodisiac for men & 20 & 29 & 69 \\
\hline Hypoxis haemerocallidea & Aphrodisiac for men & 10 & 20 & 50 \\
\hline Cannabis sativa & Vaal sick & 7 & 11 & 64 \\
\hline Tallinum caffrum & Heart related infections & 6 & 6 & 100 \\
\hline Schotia brachypetala & Diarrhoea & 6 & 6 & 100 \\
\hline Strychnos spinosa & Diarrhoea & 6 & 8 & 75 \\
\hline Acacia karoo & Diarrhoea & 6 & 6 & 100 \\
\hline Urginea sanguinea & Blood purifier & 7 & 19 & 37 \\
\hline Jatropha erythropoda & Blood purifier & 10 & 10 & 100 \\
\hline Withania somnifera & Gynaecological complaints & 14 & 14 & 100 \\
\hline Ipomoea albivenia & Gynaecological complaints & 6 & 6 & 100 \\
\hline Securidaca longipedunculata & Headache & 9 & 29 & 31 \\
\hline Cannabis sativa & Headache & 4 & 11 & 36 \\
\hline Neorautanenia mitis & Footache & 12 & 12 & 100 \\
\hline Nerium oleander & Toothache & 2 & 4 & 50 \\
\hline Sida cordifolia & High blood pressure & 6 & 6 & 100 \\
\hline Vitis vinifera & High blood pressure & 3 & 5 & 60 \\
\hline Azanza gackeana & Painful joints & 3 & 3 & 100 \\
\hline Kirkia acuminata & Fractured bones & 4 & 4 & 100 \\
\hline Aloe marlothii & Ethno-veterinary infections & 3 & 6 & 50 \\
\hline Urginea sanguinea & Ethno-veterinary infections & 7 & 19 & 37 \\
\hline Cassia abbreviata & Diabetes & 3 & 18 & 17 \\
\hline Pterodiscus kellerianus & New born babies & 18 & 18 & 100 \\
\hline Ehretia rigida & New born babies & 7 & 7 & 100 \\
\hline Grewia flavescens & New born babies & 6 & 8 & 75 \\
\hline Jartoha zeyheri & Eye infections & 14 & 26 & 53 \\
\hline Elephantorrhiza burkei & Eye infections & 10 & 36 & 27 \\
\hline Ximenia americana & Asthma & 4 & 11 & 36 \\
\hline Dichrostachys cinerea & Vomiting & 4 & 7 & 57 \\
\hline Gymnosporia senegalensis & Vomiting & 4 & 15 & 27 \\
\hline Cynodon dactylon & Tonsillitis & 3 & 3 & 100 \\
\hline Ziziphus mucronata & Tonsillitis & 3 & 4 & 75 \\
\hline Catharanthus roseus & Skin infections & 7 & 11 & 63 \\
\hline
\end{tabular}


Table 5 Fidelity levels (FL) of plant species used for various uses by key informants (Continued)

\begin{tabular}{|c|c|c|c|c|}
\hline Medicinal Plant species & Therapeutic uses & $I_{p}$ & $I_{u}$ & FL \% \\
\hline Terminalia sericea & Skin infections & 10 & 23 & 43 \\
\hline Aloe marlothii & Skin infections & 3 & 14 & 21 \\
\hline Gardenia volkensii & Chest complaints & 3 & 4 & 75 \\
\hline Cassia abbreviata & Anti-poison & 3 & 18 & 17 \\
\hline Blepharis diversispina & Deceased' wife & 23 & 29 & 79 \\
\hline Cucumis hirsuta & Deceased' wife & 26 & 26 & 100 \\
\hline Ziziphus mucronata & Sores and wounds & 1 & 4 & 25 \\
\hline Carissa edulis & Sores and wounds & 3 & 13 & 23 \\
\hline Peucedanum sulcatum & General medicine & 11 & 11 & 100 \\
\hline Ipomoea alba & General medicine & 11 & 11 & 100 \\
\hline Ipomoea spp & General medicine & 3 & 4 & 75 \\
\hline
\end{tabular}

within the Province is lagging behind and still needs to be enormously explored.

\section{Significance of names of plant species}

Some plant species in the study are named either according to their physical morphological features, growth form or their role in the traditional indigenous medicine. Urginea sanguinea is commonly known as "Sekanama" which means "like meat" referring to the blades from the bulb of the plant species and its reddish colour. Ximmenia caffra is called "Motshidikgomo". Ximmenia species are generally called "Motshidi", while the word "kgomo" means cow, which a symbol of a bigger material or object is referring to the size of the fruit of species which is bigger than other Ximmenia species. Hypoxis haemerocallidea is known as "Monna wa maledu" referring to the beed-like structures protruding from the bulb and it translates to "a man with beed". "Makgonatsohle" is a plant species which is generally used to treat all illnesses relating to stomach and it translates to "cure all" referring to the ability of the plant species to cure all illnesses. Although there is a general trend that all reddish medicinal plants are used to cleanse the blood.
"Thotamadi" is the name given to plant species and is generally believed to cleanse the bloodstream much better than all other species. "Madi" means blood. Cissus quadrangularis is indigenously known as "Mohlabadipoo". The word "hlaba" means stabbing or pinching, referring to the pinching-like feeling that a patient generally feels after fumigation of the plant species. Waltheria indica is known as Mokhutesela, refereeing to the ability of the plant species to cool the stomach. "Khuta" means heals or stops the roaring or ripens. Asparagus exuvialis is the plant species which the indigenous family that have a function at home normally burns to disperse the clouds that may cause rain when there are blackish or dark clouds which are associated with evil spirits. The idea is to let the rain come back at a later time interval. "Phatlalatsa" means disperse while "maru" refers to clouds.

Capobrotus eludis is indigenously called "tima" which means cooling off, referring to the ability of the plant species to cool off the pain, heat and fever associated with shingles, which is also known as "belt" (lepanta). Senna italica is commonly called "Morotelatshotshi". In

Table 6 Reported biological activity of the plant species with FI value $\geq 70$

\begin{tabular}{lll}
\hline Plant species & Relevant Biological activities reported by other authors & References \\
\hline $\begin{array}{l}\text { Blepharis diversispina } \\
\text { Sclerocarrya birrea }\end{array}$ & None reported & None Reported thus far. \\
Elephantorrhiza burkei & $\begin{array}{l}\text { Analgesic, anti-inflammatory, antimicrobial, anti-proliferative, } \\
\text { anti-oxidant, pro-apoptotic, anti-diarrhoeal, }\end{array}$ & {$[54-57]$} \\
Peltophorum africanum & Anti-microbial, Anti-inflammatory; & {$[37,45]$} \\
Waltheria indica & Anti-HIV, antimicrobial, anti-diabetic, anthelmintic, & {$[58,59]$} \\
Securidaca longipedunculata & Antimicrobial, Antioxidant, anti-malarial, antiviral, antidiarrheal, & {$[60,61]$} \\
& analgesic anti-inflammatory & {$[62]$} \\
Cissus quadrangularis & Antimicrobial, anti-malarial, anthelmintic, anti-inflammatory, & {$[63]$} \\
Elephantorrhiza elephantina & anti-diabetic, anti-oxidant, anti-parasitic & {$[37]$} \\
\hline
\end{tabular}


Table 7 Reported combinations of various plant species in treating infections

\begin{tabular}{|c|c|c|c|c|}
\hline $\begin{array}{l}\text { Combination } \\
\text { number }\end{array}$ & Main Medicinal plants & Other medicinal plants added & Condition treated & Mode of administration \\
\hline 1. & $\begin{array}{l}\text { Peltophorum africanum, } \\
\text { stem bark }\end{array}$ & $\begin{array}{l}\text { A handful of Elephantorrhiza } \\
\text { burkei roots, Cassia abbreviata } \\
\text { stem bark, three nodes of Cissus } \\
\text { quadrangularis }\end{array}$ & $\begin{array}{l}\text { Dropsy and other STIs on a } \\
\text { patient without sores }\end{array}$ & $\begin{array}{l}\text { The mixture is cooked in } 2 \mathrm{~L} \text { of } \\
\text { tap water in a clay pot and the } \\
\text { patient have to inhale the heat } \\
\text { coming out of pot for three } \\
\text { consecutive days. }\end{array}$ \\
\hline 2 & $\begin{array}{l}\text { Elephatorrhiza } \\
\text { elephantina, roots }\end{array}$ & $\begin{array}{l}\text { A handful of Jatropha zeyheri } \\
\text { root bark. }\end{array}$ & Eye infections & $\begin{array}{l}\text { The two plant specimen are } \\
\text { immersed in about } 500 \mathrm{~mL} \text { water } \\
\text { and the resulting solution is used } \\
\text { to wash eyes until healed. }\end{array}$ \\
\hline 3. & $\begin{array}{l}\text { Melia azeadarach, } \\
\text { Leaves }\end{array}$ & $\begin{array}{l}\text { A handful of Carpobrotus eludis } \\
\text { leaves and Catharanthus roseus } \\
\text { leaves }\end{array}$ & Shingles & $\begin{array}{l}\text { The leaves of the three plant } \\
\text { species are chopped and added } \\
\text { into a bath with mild water and } \\
\text { the patient is washed for three } \\
\text { consecutive days, three times a } \\
\text { day or until the reddishness } \\
\text { subsides. }\end{array}$ \\
\hline 4. & $\begin{array}{l}\text { Cassia abbreviata, } \\
\text { stem bark }\end{array}$ & $\begin{array}{l}\text { A handful of Elephantorhiza } \\
\text { burkei roots and Catharanthus } \\
\text { roseus roots }\end{array}$ & $\begin{array}{l}\text { Generally used to treat sexually } \\
\text { transmitted infections. }\end{array}$ & $\begin{array}{l}\text { The mixture is cooked in } 1 \mathrm{~L} \text { tap } \\
\text { water and a full cup is taken } \\
\text { orally, along a ground } \\
\text { Peltophorum africanum stem } \\
\text { bark, until the infection heals } \\
\text { completely. }\end{array}$ \\
\hline 5. & $\begin{array}{l}\text { Cassia abbreviata, } \\
\text { Stem bark }\end{array}$ & $\begin{array}{l}\text { A handful of Blepharis diversispina } \\
\text { roots, Elephantorrhiza burkei } \\
\text { roots, Jatropha zeyheri roots, } \\
\text { Cissus quadrangularis and } \\
\text { Peltophorum africanum stem bark }\end{array}$ & $\begin{array}{l}\text { Generally used to treat sexually } \\
\text { transmitted infections. }\end{array}$ & $\begin{array}{l}\text { The plant materials are cooked in } \\
\text { a } 2 L \text { water and half a cup of the } \\
\text { resulting solution is drunk three } \\
\text { times a day until the infection } \\
\text { heals completely. }\end{array}$ \\
\hline 6. & $\begin{array}{l}\text { Cassia abbreviata, } \\
\text { Stem bark }\end{array}$ & $\begin{array}{l}\text { Pollichia campestris roots, } \\
\text { "Matshilana" roots, Waltheria } \\
\text { indica roots and a handful of } \\
\text { the "Pitsa ya badisha" bulb }\end{array}$ & $\begin{array}{l}\text { Sexually transmitted infections } \\
\text { and opportunistic infections. }\end{array}$ & $\begin{array}{l}\text { The plant materials are cooked in } \\
\text { about } 3 \mathrm{~L} \text { water and two cups } \\
\text { are taken daily }\end{array}$ \\
\hline 7. & $\begin{array}{l}\text { Punica granatum, } \\
\text { Roots }\end{array}$ & $\begin{array}{l}\text { Hapargophythum procumbens } \\
\text { roots, Waltheria indica roots }\end{array}$ & Diarrhoea & $\begin{array}{l}\text { The mixture is cooked in a } 3 \mathrm{~L} \\
\text { bottle, and one cup is taken } \\
\text { along the dried and ground fruit } \\
\text { powder from Punica granatum. }\end{array}$ \\
\hline 8. & $\begin{array}{l}\text { Waltheria indica, } \\
\text { Roots }\end{array}$ & $\begin{array}{l}\text { A handful of Senna italica } \\
\text { roots, Ipomoea albivenia, } \\
\text { Hapargophythum procumbens, } \\
\text { Peltophorum africanum stem bark } \\
\text { and one small cut of Cissus } \\
\text { cornifolia bulb }\end{array}$ & Infertility & $\begin{array}{l}\text { The mixture is cooked in a } 2 \mathrm{~L} \\
\text { tap water and half a cup of the } \\
\text { resulting tea like solution is } \\
\text { drunk twice a day, treating } \\
\text { infertility. }\end{array}$ \\
\hline 9. & $\begin{array}{l}\text { Waltheria indica, } \\
\text { Roots }\end{array}$ & $\begin{array}{l}\text { A handful of various Solanum } \\
\text { species, Geigeria aspera and } \\
\text { Senna italica roots }\end{array}$ & Stomach aches and diarrhoea & $\begin{array}{l}\text { The mixture is cooked in } 2 \mathrm{~L} \text { tap } \\
\text { water and half a cup of the } \\
\text { resulting solution may be drunk } \\
\text { as often as possible, until the } \\
\text { condition is treated. }\end{array}$ \\
\hline 10. & $\begin{array}{l}\text { Grewia flavescens, } \\
\text { roots }\end{array}$ & $\begin{array}{l}\text { A handful of Waltheria indica } \\
\text { roots, Pterodiscus kellerianus roots, } \\
\text { "Matshilana" roots, Senna italica } \\
\text { roots and any three different } \\
\text { Solanum species roots }\end{array}$ & $\begin{array}{l}\text { New born meal that strengthen } \\
\text { the immunity and general } \\
\text { growth of new born babies. }\end{array}$ & $\begin{array}{l}\text { The plants are cooked in a } 3 \mathrm{~L} \\
\text { tap water and the resulting } \\
\text { solution is generally called 'disha' } \\
\text { and is sucked by babies in a milk } \\
\text { bottle. }\end{array}$ \\
\hline 11. & $\begin{array}{l}\text { Ipomoea bolusiana, } \\
\text { bulb }\end{array}$ & $\begin{array}{l}\text { A handful of and Cissus cornifolia } \\
\text { and Pollichia campestris. }\end{array}$ & Foot ache & $\begin{array}{l}\text { The mixture is cooked in a } 3 \mathrm{~L} \\
\text { clay pot, inhaled while still hot. } \\
\text { When the heat cools off, the } \\
\text { resulting mixture is poured into a } \\
\text { bin and then used to wash the } \\
\text { legs. The procedure is only done } \\
\text { in the evening or during the } \\
\text { night, once a day until the pain } \\
\text { and infection heals. }\end{array}$ \\
\hline
\end{tabular}


Table 7 Reported combinations of various plant species in treating infections (Continued)

\begin{tabular}{|c|c|c|c|c|}
\hline $\begin{array}{l}\text { Combination } \\
\text { number }\end{array}$ & Main Medicinal plants & Other medicinal plants added & Condition treated & Mode of administration \\
\hline$\overline{12 .}$ & Schotia brachypetala. & $\begin{array}{l}\text { A handful of Psidium guajava } \\
\text { roots and Dovyalis spp }\end{array}$ & Diarrhoea & $\begin{array}{l}\text { The plant materials are cooked in } \\
\text { a } 2 \mathrm{~L} \text { water and a full cup of the } \\
\text { resulting solution is reacted with } \\
\text { half a spoon of ground seeds of } \\
\text { Punica granatum. The solution is } \\
\text { mixed and then taken orally } \\
\text { three times a day until diarrhoea } \\
\text { subsides. }\end{array}$ \\
\hline
\end{tabular}

Sepedi, the word "tshotshi" refers to ants, while "moroto" means urine, which generally refers to the yellowish colour of the resulting liquid after immersing the roots in water overnight. The yellow colour may be coming out of the root kernels which are light yellow when matured. The plant species grows in abandoned ploughing land and always have ants in close proximity everywhere it grows. Indigenous taxonomy therefore makes more sense to the traditional community than the scientific society.

\section{Mode of administration}

In the current study, $73 \%$ of species are administered orally. The results in the current study corroborate that of other authors who reported the oral route as the most common mode of medicine administration [41, 42]. Besides Securidaca longipedunculata (root bark) which is taken along with mageu, all the medicinal plants species taken orally are cooked with tap water and drunk until the infections subsides or heal completely. S. longipedunculata is reported to be extremely bitter and have a lot of "after taste" and may at times result in vomiting. The use of mageu as a carrier assist in preventing such circumstances.

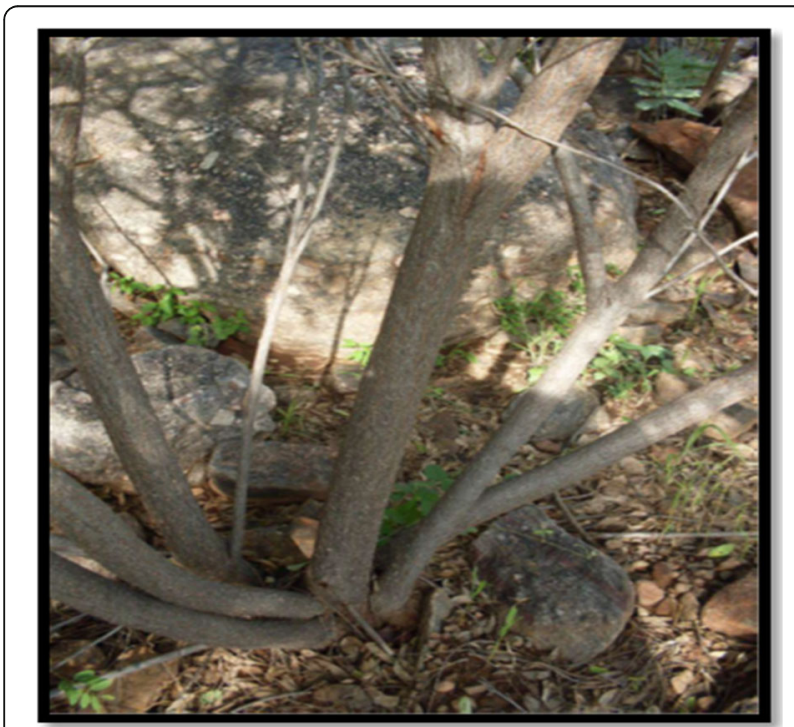

Fig. 5 Multi-stemmed Cassia abbreviata
Elsewhere, the root bark from S. longipedunculata is mixed with that of Zanthoxylum humile and taken with soft porridge to treat erectile dysfunction [43].

\section{Frequency index of documented plant species}

Except Blepharis diversispina, all the species are reported to possess a potent antimicrobial activity against a variety of pathogenic microbial strains. In a way, the results in our current study validates the affectivity of various plant species against patahogenic microbial strains. However, it is amazing that the biological activity of extracts and isolated compounds from $B$. diversispina are not explored.

Medicinal plants with the highest FI value have related ethnobotanical uses in other cultures. For example, Peltophorum africanum and Elephantorrhiza burkei have been reported in the treatment of sexually transmitted infections, skin infections and diarrhoea amongst the Tswana, VhaVenda and Tsonga cultural groups and a potency on such activities have been reported as well [44-47]. These species are of vital importance in the treatment of reported infections in combinations as shown below (Table 7). $P$. africanum has also been implicated in the treatment of various ethnoveterinary infections [48-50].

\section{Combination studies of reported plant species}

The combinations seems to be different from one traditional healer to the other. The purpose of compiling these combination studies was to assist the other researchers in selection of medicinal plant species relating to a specific illness. Earlier, [51], reported some different combination studies of related plant species, explaining that different traditional healers from different localities may use different plant species to treat different infections. The results in the current study shows that the traditional healers and plant sellers use variety of combinations in treating various ailments which includes sexually transmitted infections, eye infections, diarrhoea, and opportunistic infections associated with HIV-AIDS, new born babies illnesses and other gynaecological complaints as occurring in women. The other authors elsewhere reported the similar trend that indigenous systems use a combination of two or more plant species 
in treating infections [52]. However, from a scientific perspective, it may be difficult to determine which plant species contributes more active components than the others as there are a huge number of chemical compounds involved. However, these is generally believed to curb antimicrobial resistance.

\section{Domesticated plant species}

From our visits in the homes of the informants, we found species such as Withania somnifera, Ipomoea alba, Punica granatum, Carica papaya, Vangueria infausta, Sclerocarrya birrea, Kirkia acuminata, Cissus quadrangularis and Cassia abbreviata as some of the plant species grown in at least 10 homes. However, other authors reported most of the plant species found homes as part of a garden to be used only as food supplements and ornamental plants [53]. In our study, some plant species such as W. somnifera, $C$ quadrangularis, $K$. acuminata and I. alba are only used as medicine used to treat variety of human and animal illnesses. When asked why only those species are being domesticated, most informants believe that the plant species are used more often than others and are gradually declining in their natural environment. However, some healers believe that some plant species are believed to be efficient in treating infections only when collected from the wild. Such healers further believes that plant species in the wild are natural and have a stronger power that comes from gods and the wind.

\section{Conclusions}

The traditional knowledge of the indigenous people of Blouberg varies from one traditional healer/ plat trader to the other. Traditional medicinal plants are mostly used in the treatment of human infections, especially sexually transmitted diseases, ethno-veterinary infections, as sources of food and for magical purposes. There is correlation in terms of ethnomedicinal use between cultures within Limpopo province. There is a need to explore the wild food plants as there is lack of data in that area of research. In the current, most plant species are used in the treatment of sexually transmitted infections, management of HIV-AIDS, stomach related infections and ethno-veterinary treatment. There is a need to further explore the possibility of documenting plant species used to treat such infections in future.

\footnotetext{
Acknowledgements

Sylvester Lethulatshipi, Benjamin Mokgehle, Tlou Mongalo, Terrence Mongalo, Clerrence Mongalo, Ofentse Mongalo, Mphasha Molefe and Lethabo Mashita assisted with field work, plant collection and data gathering. The authors are also thankful to the traditional healers and the plant sellers who contributed their knowledge towards the successful completion of the research work.
}

\section{Funding}

The authors would like to express their deepest gratitude to the National Research Foundation (Grant Unique Number 94179, University of South Africa) for financial support to conduct this research.

\section{Availability of data and materials \\ Raw data is contained in questionnaire forms and cannot be shared in this form.}

\section{Authors' contributions}

MTJ contributed to the proposal of the idea. MTJ and MNI carried out the field work laboratory work and data analysis while MTJ wrote the first draft. $\mathrm{MNI}$ collected, pressed, identified and contributed to the statistical analysis, ethnobotanical assistance, and wrote the final draft. MTJ is the Director of Research at Mangosuthu University of Technology (South Africa), while MNI is a laboratory Technician under Plant Sciences (University of South Africa), Florida Campus. Both authors read and approved the final manuscript.

\section{Ethics approval and consent to participate}

This study was approved by the University of South Africa's Research Ethics Committee. Before conducting interviews, all participants signed the consent form.

\section{Consent for publication}

This manuscript does not contain any individual person's data and therefore, there is no further consent is required for publication.

\section{Competing interests}

The authors declares that they have no conflict of interest.

\section{Publisher's note}

Springer Nature remains neutral with regard to jurisdictional claims in published maps and institutional affiliations.

\section{Author details}

${ }^{1}$ College of Agriculture and Environmental Science (CAES) Laboratories, University of South Africa, Private BagX06, Johannesburg 0710, South Africa. ${ }^{2}$ Research, Innovation \& Engagements Portfolio, Mangosuthu University of Technology, P O Box 12363, Durban 4026, South Africa.

Received: 14 August 2017 Accepted: 18 June 2018

Published online: 13 July 2018

References

1. Statistics South Africa, 2011. Provincial profile: Limpopo Census 2011, Report No. 03-01-78.

2. York T, De Wet H, Van Vuuren SF. Plants used for treating respiratory infections in rural Maputaland, KwaZulu-Natal, South Africa. J Ethnopharmacol. 2011;135: 696-710.

3. Corrigan BM, Van Wyk BE, Geldenhuys CJ, Jardine JM. Ethnobotanical plant uses in the Kwa-Nibela peninsula, St Lucia, South Africa. S Afr J Bot. 2011;77: 346-59.

4. Chinsembu KC. Ethnobotanical study of medicinal flora utilised by traditional healers in the management of sexually transmitted infections in Sesheke District, Western Province, Kenya. Brazillian J Pharmacognosy. 2016;26:268-74.

5. Semenya SS, Potgieter MJ. Bapedi traditional healers in the Limpopo Province, South Africa: their socio-cultural profile and traditional healing practice. J Ethnobiol Ethnomed. 2014;10:4

6. Semenya SS, Maroyi A. Medicinal plants used by the Bapedi traditional healers to treat diarrhoea in the Limpopo Province, South Africa. J Ethnopharmacol. 2012;144:395-401.

7. Semenya SS, Potgieter MJ, Erasmus LJC. Indigenous plant species used by Bapedi healers to treat sexually transmitted infections: their distribution, harvesting conservation and threats. S Afr J Bot. 2013;87:66-75.

8. Mahwasane ST, Middleton L, Boaduo N. An ethnobotanical survey of indigenous knowledge on medicinal plants used by the traditional healers of the Lwamondo area, Limpopo Province, South Africa. S Afr J Bot. 2013:88:69-75.

9. Masevhe NA, McGaw LJ, Eloff JN. The traditional use of plants to manage candidiasis and related infections in Venda, South Africa. J Ethnopharmacol. 2015;168:364-72. 
10. Van Wyk BE, De Wet H, Van Heerden FR. An ethnobotanical survey of medicinal plants in the south eastern Karoo, South Africa. S Afr J Bot. 2008; 74:696-704.

11. Ajibesin KK, Ekpo BA, Bala DN, Essien EE, Adesanya SA. Ethnobotanical survey of Akwa Ibom state of Nigeria. J Ethnopharmacol. 2008;1 15:387-408.

12. Jeruto $P$, Lukhoba C, Ouma G, Otieno D, Mutai C. An ethnobotanical study of medicinal plants used by the Nandi people of Kenya. J Ethnopharmacol. 2008;116:370-6.

13. Maroyi A. An ethnobotanical survey of medicinal plans used by the people of Nhema communal area, Zimbabwe. J Ethnopharmacol. 2011;136:347-54.

14. Kose LS, Moteetee A, Van Vuuren S. Ethnobotanical survey of medicinal plants used in the Maseru District of Lesotho. J Ethnopharmacol. 2015;170: 184-200.

15. Nortje JM, Van Wyk BE. Medicinal plants of the Kamiesberg, Namaqualand, South Africa. J Ethnopharmacol. 2015;171:205-22.

16. Karimi A, Majlesi M, Rafieian-Kopaei M. Herbal versus synthetic drugs; beliefs and facts. J Nephropharmacology. 2015:4(1):27-30.

17. Tshikalange TE, Meyer JJM, Hussein AA. 2005. Antimicrobial activity, toxicity and the isolation of a bioactive compound from plants used to treat sexually transmitted diseases. J Ethnopharmacol. 2005;96:515-9.

18. Taylor JLS, Rabe T, McGaw LJ, Jäger AK, Van Staden J. Towards the scientific validation of traditional medicinal plants. Plant Growth Regul. 2001;34:23-37.

19. Afolayan AJ, Grierson DS, Mbeng WO. Ethnobotanical survey of medicinal plants used in the management of skin disorders among the Xhosa communities of the Amathole District, eastern cape, South Africa. J Ethnopharmacol. 2014;153:220-32.

20. Gail H, Tarryn B, Oluwaseyi A, Denver D, Oluchi M, Charlotte VK, Joop DJ, Diana $\mathrm{G}$. An ethnobotanical survey of medicinal plants used by traditional health practitioners to manage HIV and its related opportunistic infections in Mpoza, eastern Cape Province, South Africa. J Ethnopharmacol. 2015;171:109-15.

21. Tchouya GRF, Souza A, Tchouankeu JC, Yala JF, Boukandou M, Foundikou H, Obiang GDN, Boyom FF, Mabika RM, Menkem EZ, Ndinteh DT, Lebibi J. Ethnopharmacological surveys and pharmacological studies of plants used in traditional medicine in the treatment of HIV-AIDS opportunistic diseases in Gabon. J Ethnopharmacol. 2015;162:306-16.

22. Mongalo NI. Antibacterial activities of selected medicinal plants used to treat sexually transmitted infections in Blouberg area, Limpopo Province. MSc dissertation, University of Zululand, republic of south Africa 2013.

23. Statistic South Africa Semi-permanent data estimated by National Department of Health in Mid-2006 by Disaggregating Province and District estimates using data from Small Area Layer. (2004-2006).

24. Koné WM, Atindehou KK. Ethnobotanical inventory of medicinal plants used in traditional veterinary medicine in northern cote d'Ivore (West Africa). S Afr J Bot. 2008:74:76-84.

25. Madikizela B, Ndhlala AR, Finnie JF, Van Staden J. An ethnobotanical study of plants from Pondoland used against diarrhoea. J Ethnopharmacol. 2012 141:61-71.

26. Chinsembu KC, Negumbo J, Likando M, Mbangu A. An ethnobotanical study of medicinal plants used to treat livestock diseases in Onayena and Katima Mulilo, Namibia. S Afr J Bot. 2014;94:101-7.

27. Kankara SS, Ibrahim MH, Mustafa M, Go R. Ethnobotanical survey of medicinal plants used for traditional maternal healthcare in Katsina state, Nigeria. S Afr J Bot. 2015;97:165-75.

28. Tugume P, Kakudidi EK, Buyinza M, Namaalwa J, Kamatenesi M, Mucunguz P, Kalema J. Ethnobotanical survey of medicinal plant species used by communities around Mabira central Forest reserve, Uganda. J Ethnobiol Ethnomed. 2016:12:5.

29. Inngjerdingen K, Nergard CS, Diallo D, Mounkoro PP, Paulse BS. An ethnopharmacological survey of plants used for wound healing in Dogonland, Mali, West Africa. J Ethnopharmacol. 2004;92:233-44.

30. Gakuya DW, Itonga SM, Mbaria JM, Muthee JK, Musau JK. Ethnobotanical survey of biopesticides and other medicinal plants traditionally used in Meru central district of Kenya. J Ethnopharmacol. 2013;145:547-53.

31. Davids D, Gibson D, Johnson Q. Ethnobotanical survey of medicinal plants used to manage high blood pressure and type 2 diabetes mellitus in Bitterfontein, western cape. Province J Ethnopharmacology. 2016;194:755-66.

32. Urso V, Signorini MA, Tonini M, Bruschi P. Wild medicinal and food plants used by communities living in mopane woodlands of southern Angola: results of an ethnobotanical field investigation. J Ethnopharmacol. 2016;177: $126-39$.
33. Cheikhyoussef A, Shapi M, Matengu K, Ashekele HM. Ethnobotanical study of indigenous knowledge on medicinal plant use by traditional healers in Oshikoto region. Namibia J Ethnobiol Ethnomed. 2010;7:10.

34. Uddin MZ, Hassan A. Determination of informant consensus factor of ethnomedicinal plants used in Kalenga forest, Bangladesh. Bangladesh J Plant Taxonomy. 2014;21:83-91.

35. Song MJ, Kim H, Heldenbrand B, Jeon J, Lee S. Ethnopharmacological survey of medicinal plantsin Jeju Island, Korea. J Ethnobiol Ethnomed. 2013;9:48.

36. Ajibesin KA, Bala DN, Umoh UF. Ethno medicinal survey of plants used by the indigenes of rivers state of Nigeria. Pharm Biol. 2012;50:1123-43.

37. Mathabe MC, Nikolova RV, Lall N, Nyazema NZ. Antibacterial activities of medicinal plants used for the treatment of diarrhoea in Limpopo Province. South Africa J Ethnopharmacology. 2016;105:283-93.

38. Peltzer K, Mngqundaniso N, Petros G. HIV/AIDS/TB knowledge, beliefs and practices of traditional healers in KwaZulu-Natal, South Africa. AIDS Care. 2006;18:608-13.

39. Mongalo NI, Mafoko B. Cassia abbreviata Oliv. A review of its ethnomedicinal uses, toxicology, phytochemistry, possible propagation techniques and pharmacology. Afr J Pharm Pharmacol. 2013;7:2901-6.

40. Musina GKE, Maroyi A. Edible plants of urban domestic gardens in the Capricorn District, Limpopo Province. South Africa Tropical Ecology. 2016:57:181-91.

41. Otang WM, Grierson DS, Ndip RN. Ethnobotanical survey of medicinal plants used in the management of opportunistic fungal infections in HIV/AIDS patients in the Amathole district of the eastern Cape Province, South Africa. J Med Plants Res. 2012;6:2071-80.

42. Mesfin F, Demissew S, Teklehaymanot T. An ethnobotanical study of medicinal plants in Wonago Woreda, SNNPR, Ethiopia. J Ethnobiol Ethnomed. 2009:5:28.

43. Semenya SS, Potgieter MJ. Ethnobotanical survey of medicinal plants used by Bapedi traditional healers to treat erectile dysfunction in the Limpopo Province. South Africa J Med Plants Res. 2013;7:49-357.

44. Mulaudzi RB, Ndhlala AR, Kulkarni MG, Finnie JF, Van Staden J. Antimicrobial properties and phenolic contents of medicinal plants used by the Venda people for conditions related to venereal diseases. J Ethnopharmacol. 2011; 135:330-7.

45. Mulaudzi RB, Ndhlala AR, Kulkarni MG, Finnie JF, Van Staden J. AntiInflammatory and anti-mutagenic evaluation of medicinal plants used by the Venda people against venereal and related diseases. J Ethnopharmacol. 2013;146:173-9.

46. Van Wyk B, Gericke N. Peoples' plants: a guide to useful plants of southern Africa, 2007; First Edition, Third Impression, Briza Publications, Pretoria p. 130.

47. Moeng TE. An investigation into the trade of medicinal plants by muthi shops and street vendors in the Limpopo Province, South Africa master of science dissertation. University of Limpopo, south. Africa. 2010;

48. Motlhanka DMT, Nthoiwa GP. Ethnobotanical survey of medicinal plants of Tswapong north, in eastern Botswana: a case of plants from Mosweu and Seolwane villages. European J Med Plants. 2013:3:10-24.

49. Moreki JC. Use of ethnoveterinary medicine in family poultry health management in Botswana: a review. J Vet Adv. 2012;2:254-60.

50. Moreki JC, Tshireletso K, Okoli IC. Potential use of ethnoveterinary medicine for retained plancenta in cattle in Mogonono. Botswana J Anim Prod Adv. 2012;2:303-9.

51. Mongalo NI. Antibacterial activities of selected medicinal plants used to treat Sex Transm Infect in Blouberg area, Limpopo Province. MSC Dissertation: University of Zululand: 2013.

52. Simbo DJ. An ethnobotanical survey of medicinal plants in Babungo, northwest region, Cameroon. J Ethnobiol Ethnomed. 2010;6:8.

53. Licata L, Tuttolomondo T, Leto C, Virga G, Bonsangue G, Cammalleri I, Gennaro MC, La Bella S. A survey of wild plant species for food use in Sicily (Italy) - results of a 3-year study in four regional parks. J Ethnobiology Ethnomedicine. 2016;12:12.

54. Galvez J, Zarzuelo A, Crespo ME, Utrilla MP, Jiménez J, Spiessens C, De Witte $P$. Antidiarrhoeic activity of Sclerocarya birrea bark extract and its active tannin constituent in rats. Phytother Res. 1991;5:276-8.

55. Ojewole JAO. Evaluation of the analgesic, anti-inflammatory and antidiabetic properties of Sclerocarna birrea (a. Rich.) Hochst. Stem bark aqueous extract in mice and rats. Phytother Res. 2004;18:601-8.

56. Tanih NF, Ndip RN. 2013. The acetone extract of Sclerocarrya birrea (Anacardiaceae) possess anti-proliferative and apoptotic potential against human breast cancer cell lines (MCF-7). The scientific world journal 2013; article ID956206. 
57. Armentano MF, Bisaccia F, Miglionico R, Russo D, Nolfi N, Carmosino M, Andrade PB, Valent O P, Diop MS, Milella L. Antioxidant and proapoptotic activities of Sclerocarrya birrea [(a. Rich.) Hochst] methanolic root extracton the hepatocellular carcinoma cell line HepG2. Biomed Res Int 2015; Article ID561589.45.

58. Mazimba, O. Pharmacology and phytochemistry studies in Peltophorum africanum. Bulletin in Faculty of Pharmacy, Cairo University 2014;52, 145-153.

59. Mongalo NI. Peltophorum africanum Sond [Mosetha]: a review of its ethnomedicinal uses, toxicology, phytochemistry and pharmacological activities. J Med Plants Res. 2013;7:3484-91.

60. Zongo F, Ribout C, Boumendjel A, Guissou I. Botany, traditional uses, phytochemistry and pharmacology of Waltheria indica L. (syn. Waltheria Americana): a review. J Ethnopharmacol. 2013;148:14-26.

61. Mongalo NI, Opoku AR, Zobolo AM. Antibacterial and antioxidant activity of the extracts of Waltheria indica Linn. Collected from, Capricorn District, Limpopo Province, South Africa. J Med Plant Res. 2012;43:5593-8.

62. Mongalo NI, McGaw $\sqcup$, Finnie JF, Van Staden J. Seruridaca longipedunculata Fresen. A review of its ethnomedicinal uses, phytochemistry, pharmacological properties and toxicology. J Ethnopharmacol. 2015;165:215-26.

63. Mishra G, Srivastava S, Nagori BP. Pharmacological and therapeutic activity of Cissus quadrangularis: an overview. Int J PharmTech Research. 2010;2: $1298-310$

Ready to submit your research? Choose BMC and benefit from:

- fast, convenient online submission

- thorough peer review by experienced researchers in your field

- rapid publication on acceptance

- support for research data, including large and complex data types

- gold Open Access which fosters wider collaboration and increased citations

- maximum visibility for your research: over $100 \mathrm{M}$ website views per year 